\title{
Trinidad and Tobago: Selected Issues
}

This selected issues paper on Trinidad and Tobago was prepared by a staff team of the International Monetary Fund as background documentation for the periodic consultation with the member country. It is based on the information available at the time it was completed on January 7, 2011. The views expressed in this document are those of the staff team and do not necessarily reflect the views of the government of the Trinidad and Tobago or the Executive Board of the IMF.

The policy of publication of staff reports and other documents by the IMF allows for the deletion of market-sensitive information.

\author{
Copies of this report are available to the public from \\ International Monetary Fund • Publication Services \\ $70019^{\text {th }}$ Street, N.W. • Washington, D.C. 20431 \\ Telephone: (202) 623-7430 • Telefax: (202) 623-7201 \\ E-mail: publications@imf.org Internet: http://www.imf.org
}

\section{International Monetary Fund Washington, D.C.}




\section{INTERNATIONAL MONETARY FUND \\ TRINIDAD AND TOBAGO}

\section{Selected Issues}

Prepared by Hunter Monroe and Yi Wu (both WHD)

Approved by Western Hemisphere Department

January 7, 2011

Contents

Page

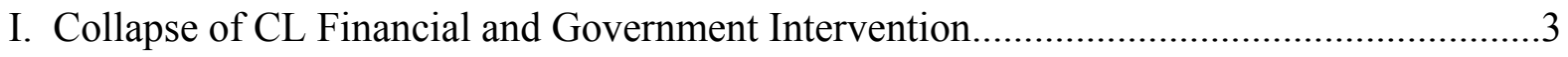

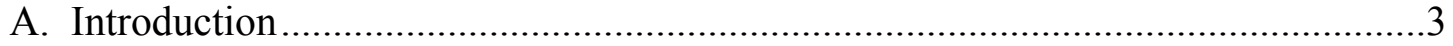

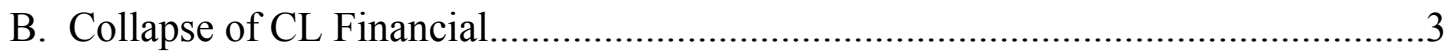

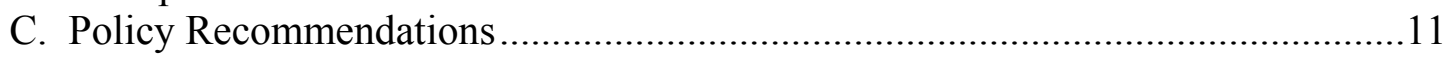

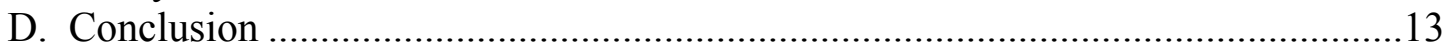

Box

1. Core Principles for Effective Insurance Supervision.......................................................12

Chart

1. CL Financial Organizational Structure, 2007 ....................................................................

Table

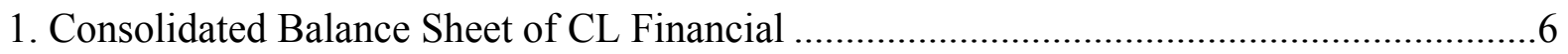

Appendix

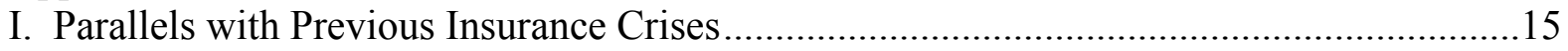

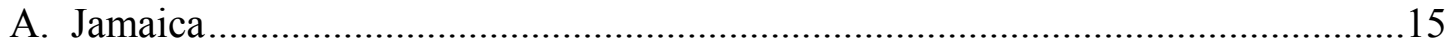

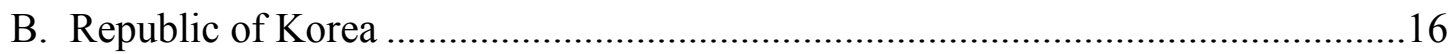

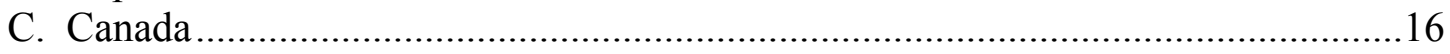

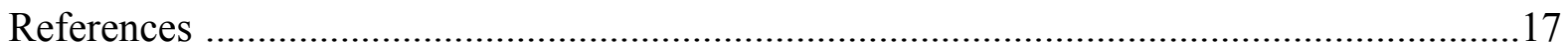

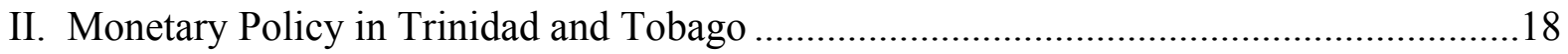

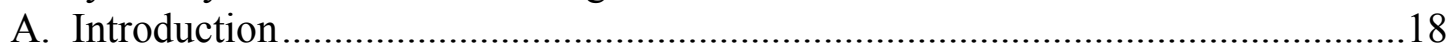

B. Objectives, Instruments, and Constraints for Monetary Policy ………………......18

C. Monetary Developments ………………………………………………….....2

D. Effectiveness of the Repo Rate as a Monetary Policy Instrument ..........................21

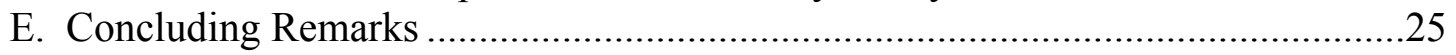




\section{Table}

1. Impulse Responses From VAR Analyses ....

Figures

1. Reserve Requirement and OMOs .18

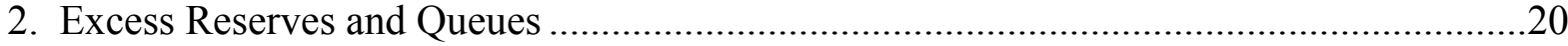

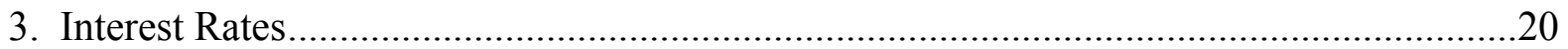

4. Commercial Bank Credit to Private Sector.....................................................................21

5. Commercial Bank's Borrowing From the Repo Window ...........................................23

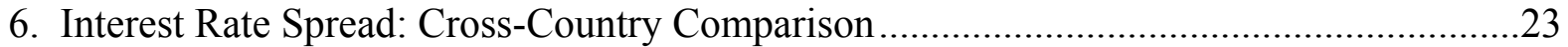

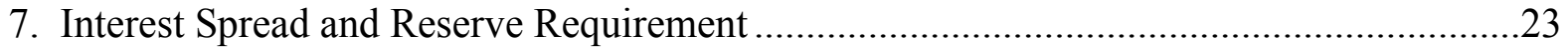

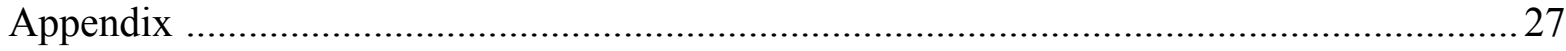

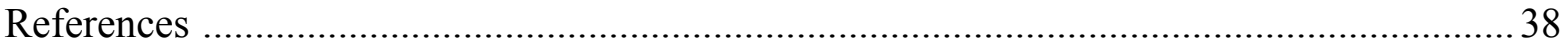




\section{COLLAPSE OF CL FINANCIAL AND GOVERNMENT INTERVENTION ${ }^{1}$}

\section{A. Introduction}

\section{The January 2009 collapse of Trinidad and Tobago-based CL Financial Limited} (CLF) and related companies has represented a major financial shock to the Caribbean, which was already reeling from the global crisis. The collapse has had spillover effects in all 15 CARICOM states except for Jamaica and Haiti, with exposures as high as 17 percent of GDP in the Eastern Caribbean, leading to costly government interventions. CLF's insurance subsidiaries, the Colonial Life Insurance Company (CLICO), the British American Insurance Company (BAICO), and related companies took in funds via deposit-like investment products as well as through traditional insurance and pension products, and channeled these to over-leveraged sister companies and real estate developments which have sharply lost value during the global crisis. The collapse has placed at risk the assets of a wide range of depositors, investors and policyholders, including individuals, corporate and public pension schemes, and financial institutions. The government intervention of CLICO, British American Insurance Trinidad (BAT), and CLICO Investment Bank helped contain contagion, but the cost net of assets could be as high as TT $\$ 13.6$ billion (10 percent of GDP), including the TT $\$ 7.3$ billion already injected.

2. This paper provides some background to the developments that led to the crisis, describes how the crisis evolved, and assesses the business practices and regulatory weaknesses which led to the collapse. It also describes policy responses to date to address the crisis and to prevent a recurrence, and presents key policy lessons on putting in place sturdy regulatory frameworks. Section BI describes the precursors to the collapse of CLF and efforts to resolve the crisis. Section $\mathrm{C}$ presents policy lessons and recommendations for strengthening the regulatory framework. Section D concludes, and an Appendix describes insurance sector crises and their resolution in Jamaica, the Republic of Korea, and Canada.

\section{B. Collapse of CL Financial}

\section{CLF grew out of the Colonial Life Insurance Company (CLICO) founded in} 1937. CLF was created in 1993 as a holding company as operations expanded beyond insurance into other sectors, including energy, financial services, real estate, and the beverages industry. According to the company's 2007 annual report, the last one published, the consolidated assets of CLF were about US\$16 billion-equal to some 30 percent of the

\footnotetext{
${ }^{1}$ This chapter was prepared by Hunter Monroe. It covers developments to January 6, 2011. The author is grateful to the authorities for providing information and clarification; to Judith Gold, Philip Liu, and Yi Wu for valuable comments and suggestions; to Lulu Shui for excellent research assistance; and to Sherrie Barnes for her assistance in preparing the manuscript.
} 
Caribbean region's GDP. ${ }^{2}$ The conglomerate has operations in at least 28 countries through at least 52 subsidiaries and associates in a complex structure (see Chart 1). It has majority ownership of the largest commercial bank, Republic Bank, and owns the largest insurance company in Trinidad and Tobago, CLICO (Trinidad) which had assets of US\$2.9 billion at end-2008 (11 percent of Trinidad and Tobago's GDP). The conglomerate's enormous size may have contributed to a sense of security by policy holders.

\section{Precursors to the Collapse}

\section{As CLF expanded into other sectors, a key source of financing for its expansion} particularly after 2004 was the offer of deposit-like annuity products through CLF's insurance subsidiaries - CLICO Trinidad which operated primarily in the domestic market and British American which operated in many countries of the region. The products offered returns that were substantially higher than bank interest rates but were not subject to stricter banking regulation and supervision. As described below, the rapid growth in illiquid assets concentrated in these sectors, through connected exposures financed by comparatively liquid liabilities, set the stage for the collapse.

5. CLF's assets grew by 32 percent during 2005-07 (see Table 1). As of end-2007, about 25 percent of total assets were illiquid assets in the form of properties, including investment properties, plant and equipment, and land for development. These included real estate investments in Florida and petrochemical plants. During 2005-2007, property holdings increased by 78 percent.

\section{A significant portion of CLF's}

liabilities comprised insurance contracts, borrowing, and deposits. Of particular concern were the deposit-like products called Flexible Premium Annuities and Executive Flexible Premium Annuities. These were sold for a fixed term of 3-5 years, paid interest of 8-9 percent and up to 11 percent for large local currency deposits, with a penalty for early surrender before the instrument matured. By contrast, the ordinary savings deposit rate in 2006-08

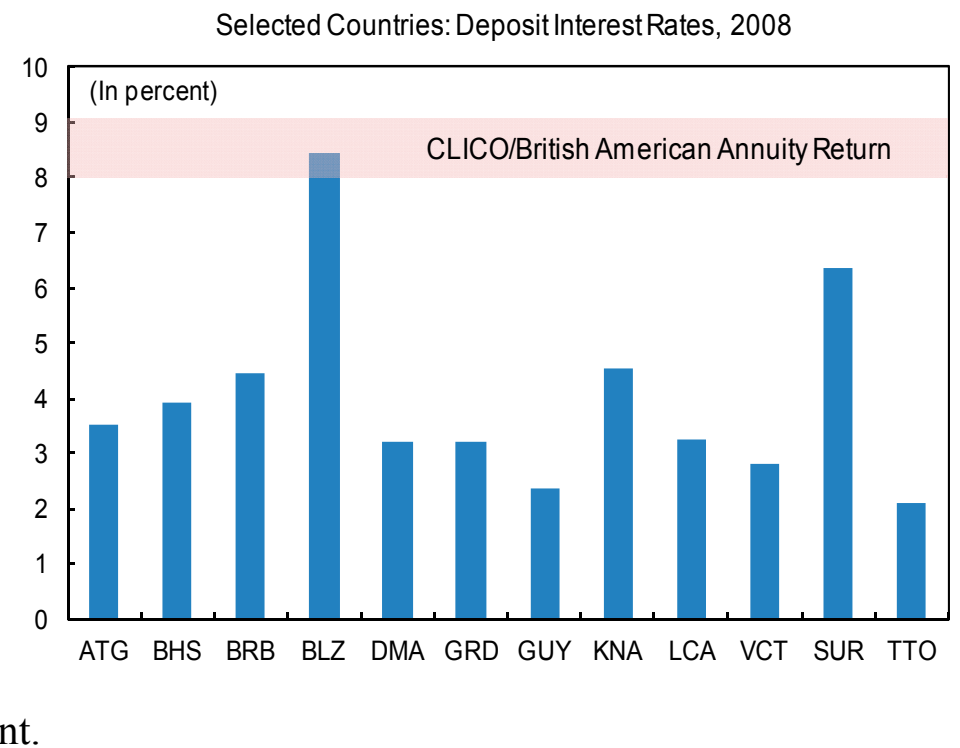
in Trinidad and Tobago was about 2 percent.

\footnotetext{
${ }^{2}$ The conglomerate is privately owned, and more recent financial data, either at a consolidated or subsidiary level, has not been readily available to the public.
} 
Chart 1. CL Financial Organizational Structure, 2007

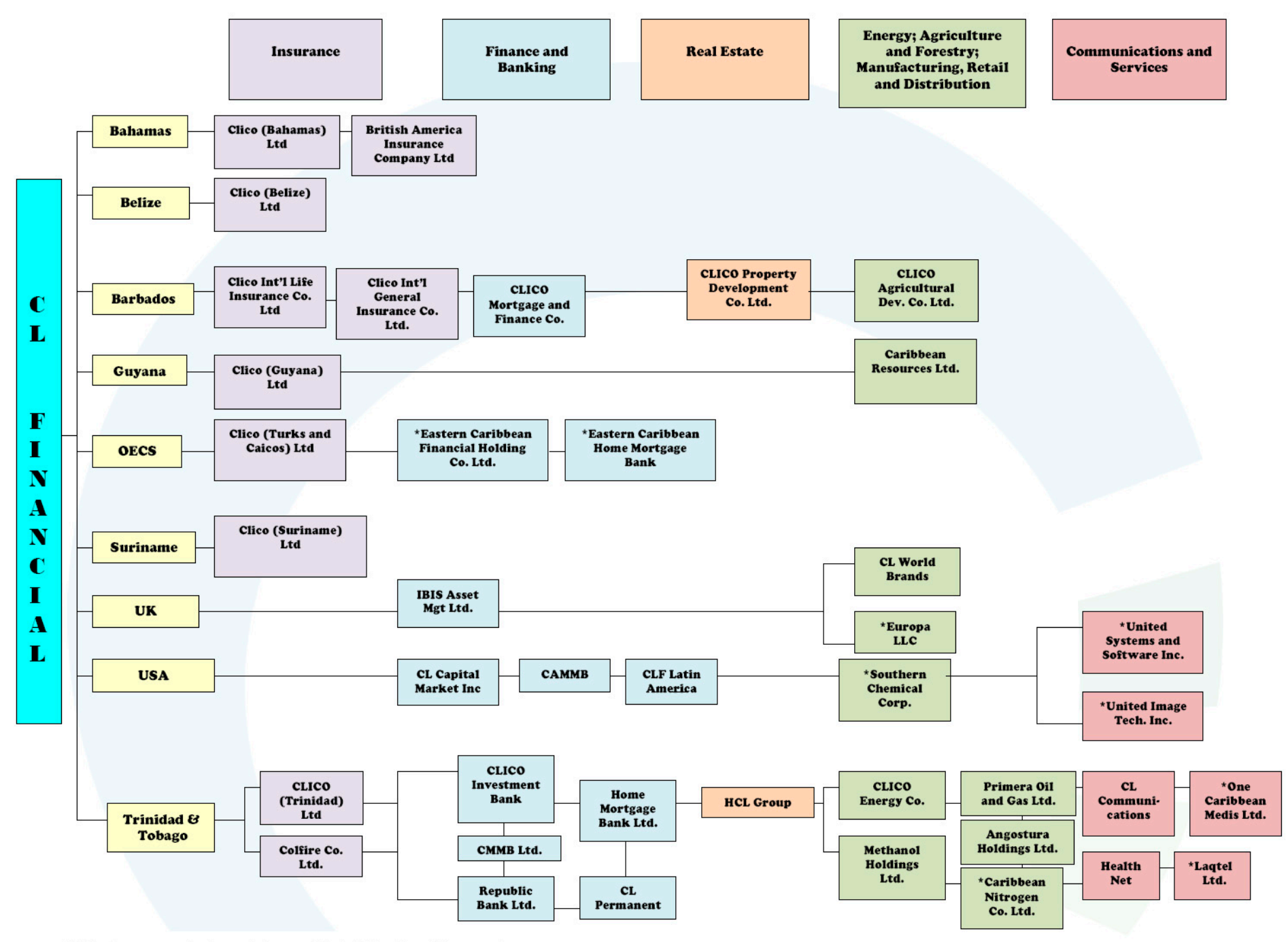

Note: * represents Associates and Joint Venture Companies

Source: CL Financial Annual Report 2007 and http://www.clfinancial.com 
Table 1. Consolidated Balance Sheet of CL Financial

\begin{tabular}{|c|c|c|c|}
\hline & 2005 & 2006 & 2007 \\
\hline \multicolumn{4}{|c|}{ (In billions of U.S. dollars) } \\
\hline Assets & 12.1 & 14.1 & 16.0 \\
\hline Properties & 2.2 & 2.8 & 3.9 \\
\hline Loans and advances & 2.8 & 3.2 & 3.5 \\
\hline Financial assets & 3.5 & 3.7 & 3.3 \\
\hline Cash & 1.1 & 1.5 & 1.9 \\
\hline Other & 2.4 & 2.9 & 3.3 \\
\hline Liabilities & 10.9 & 12.9 & 14.6 \\
\hline Insurance contracts & 1.8 & 2.2 & 2.9 \\
\hline Borrowings & 1.1 & 1.3 & 2.4 \\
\hline Deposits & 4.0 & 4.5 & 4.7 \\
\hline Other current liabilities & 3.1 & 3.4 & 3.3 \\
\hline Other & 1.0 & 1.4 & 1.3 \\
\hline Equity & 1.1 & 1.2 & 1.3 \\
\hline \multicolumn{4}{|c|}{ (In percent of total assets) } \\
\hline Assets & 100.0 & 100.0 & 100.0 \\
\hline Properties & 18.0 & 20.1 & 24.8 \\
\hline Loans and advances & 23.3 & 22.5 & 21.9 \\
\hline Financial assets & 29.4 & 26.0 & 20.8 \\
\hline Cash & 9.1 & 10.9 & 11.6 \\
\hline Other & 20.2 & 20.6 & 21.0 \\
\hline Liabilities & 90.5 & 91.3 & 91.6 \\
\hline Insurance contracts & 15.2 & 15.6 & 17.9 \\
\hline Borrowings & 8.8 & 9.5 & 14.7 \\
\hline Deposits & 32.9 & 31.8 & 29.7 \\
\hline Other current liabilities & 25.4 & 24.1 & 21.0 \\
\hline Other & 8.1 & 10.3 & 8.3 \\
\hline Equity & 9.5 & 8.7 & 8.4 \\
\hline \multicolumn{4}{|l|}{ Memorandum item: } \\
\hline Exchange rate (TT\$ per US\$) & 6.3 & 6.3 & 6.3 \\
\hline
\end{tabular}

Source: Annual Reports of CL Financial Group and

the Central Bank of Trinidad and Tobago.

\section{CLF sold these as well as traditional insurance products throughout the} Caribbean via CLF's network of insurance subsidiaries and branches in 22 countries. These included CLICO affiliates in The Bahamas, Barbados, the Cayman Islands, Guyana, Panama, and Suriname. CLICO Barbados and another subsidiary, BAICO Bahamas, operated in the eight members of the Eastern Caribbean Currency Union (ECCU). ${ }^{3}$ CLICO Bahamas operated subsidiaries in Belize and Turks and Caicos Islands.

\footnotetext{
${ }^{3}$ The members of the ECCU are: Anguilla, Antigua and Barbuda, Dominica, Grenada, Montserrat, St. Kitts and Nevis, St. Lucia, and St. Vincent and the Grenadines. Although BAICO was legally headquartered in the Bahamas, it operated from Trinidad.
} 


\section{Insurance Regulatory Framework}

8. The insurance sector in Trinidad and Tobago is governed by the Insurance Act of 1966. The Central Bank took over supervision of the insurance sector in 2004. To address shortcomings of the Act, the Central Bank issued Guidelines on matters including corporate governance, prudent lending, and claims handling. Financial returns are required quarterly, and companies are subject to on-site inspections roughly every $1 \frac{1 / 2}{2}$ years. Enforcement has been constrained by legal challenges to these Guidelines and the Act.

\section{According to IMF's 2005 Financial System Stability Assessment (FSSA), there} were critical gaps in the overall legal, regulatory and supervisory structure for the insurance sector. Despite considerable strengthening of financial supervision, the framework was not fully aligned with the evolution of the financial system. Financial sector legislation did not endow regulators with sufficient formal powers to oversee cross-market and cross-border activities, and issues such as prudential and market conduct aspects of the insurance business.

\section{Collapse and Intervention}

10. With the deterioration of global economic conditions in 2008, many of CLF's subsidiaries faced liquidity and solvency pressures. Methanol Holdings, one of the largest methanol producers in the world and a big contributor of dividends to CLF, suffered a collapse in methanol prices. Real estate investments in Florida held by regional BAICO and CLICO affiliates turned sour. As news of CLF's difficulties spread, withdrawal requests from policyholders increased, and shortfalls in the statutory funds of many insurance entities became acute.
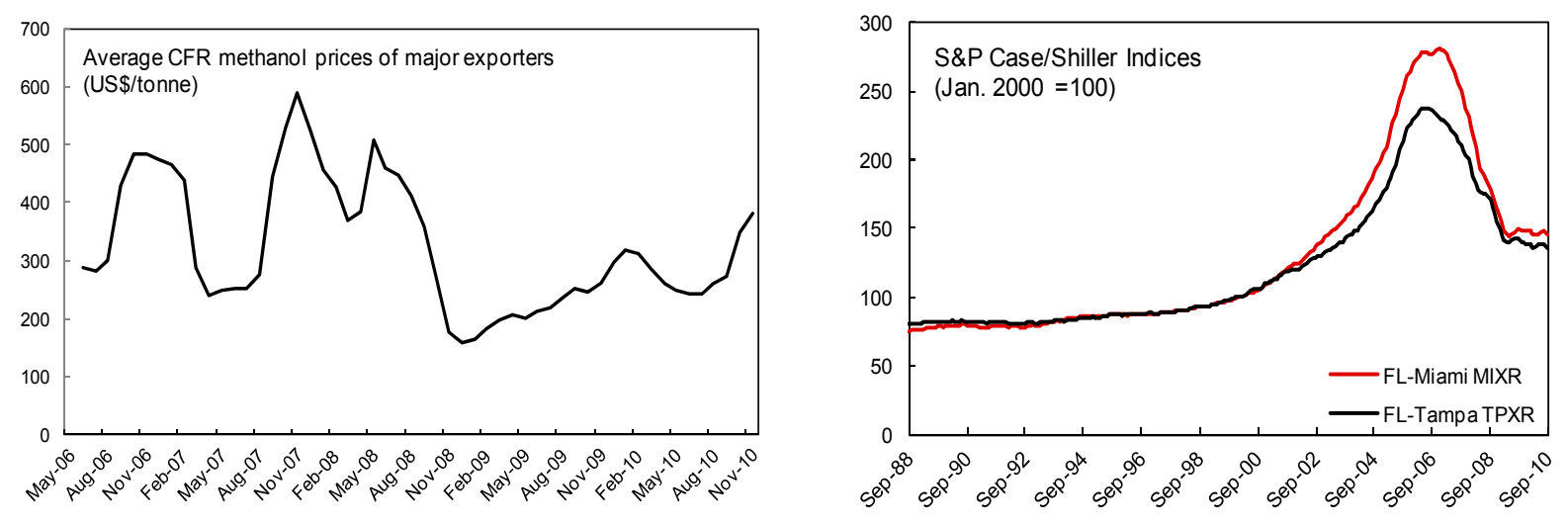

11. The Trinidad and Tobago authorities intervened in the affairs of CLF in January 2009 and announced a financial support package for three domestic subsidiaries: CLICO, Trinidad BAT, and CIB. In the announcement, the Central Bank identified the key factors leading to the intervention as: 
- Excessive related-party transactions which carry significant contagion risks,

- An aggressive high interest rate resource mobilization strategy to finance equally high risk investments, and

- Very high leveraging of the CLF's assets, which constrains the potential amount of cash that could be raised from the asset sales.

The Central Bank indicated that it was aware of these deficiencies but had been "stymied by the inevitable challenge of change and by inadequacies in the legislative framework which do not give the Bank the authority to demand these changes."

\section{As part of the government intervention, an agreement was reached with the} shareholders of CLF. Under the January 2009 memorandum of understanding (MoU) with the government, the shareholders of CLF agreed to take steps to correct the financial condition of CIB, CLICO Trinidad, and BAT by selling its stake in Republic Bank, Methanol Holdings Trinidad, and the Caribbean Money Market Brokers and any other assets as necessary. The Central Bank assumed control of CIB, CLF agreed to sell assets to meet the statutory fund requirements for CLICO Trinidad and BAICO Trinidad, and the government agreed to provide loan financing to meet those requirements. The government injected an initial US\$191 million. An amendment to the Insurance Act in February 2009 addressed shortcomings in the legal framework by requiring quarterly reporting, by requiring that statutory fund requirements be met on an ongoing basis and not only at the end of the year, by implementing timely corrective action by insurance companies, and by authorizing information sharing among regulators. It was also announced in February that CIB's thirdparty deposits would be transferred to the First Citizens Bank.

\section{Subsequently, another agreement was signed in June 2009 under which the} authorities gained a greater say in management to ensure that the assets owned by and managed by CLF would provide a source to repay the government. The new agreement required the appointment of a new Board of Directors of CLF with majority government representation and established an escrow account for the proceeds of any asset sales. The chairman of CLF was replaced shortly thereafter.

\section{The difficulties of CLICO were initially perceived to be a liquidity problem} which would be resolved as assets were sold and as the economy recovered. The objective stated at the time of the intervention was to "return CLICO to its original moorings." Annuity holders were encouraged to roll over policies, and payouts were made to the extent possible.

\section{In June 2010, the new government elected in May announced that repaying} principal only to CLICO policy holders would require a further injection of capital. It charged a Select Committee with recommending a preferred solution for the repayment of 
CLICO's traditional and non-traditional insurance liability products; a financial reorganization plan for CLF that demonstrates financial stability and ensures full satisfaction of commercial and inter-company debt; and a clear path and timetable on how the government will exit its loan capital position and restore public confidence.

\section{In line with the Committee's recommendation, the September 2010 budget} speech announced a restructuring plan that would pay all investors in full up to a threshold (TT\$75,000 or US\$12,000) and pay the remainder over 20 years with no interest. Payments by CLICO to holders of nontraditional insurance products stopped at that time. The traditional insurance businesses of CLICO and BAICO would be combined and divested. The plan to restructure payments has met strong opposition from policyholders and after a review, is moving forward with modifications to provide a liquidity support window for credit unions and a compassionate window for vulnerable individuals.

\section{Spillover Effects}

\section{Because BAICO and to a limited extent CLICO Trinidad drew funds} throughout the Caribbean, the collapse of CLF has had large spillover effects affecting all 15 CARICOM states except for Jamaica and Haiti.

- Barbados: In February 2009, following the difficulties of CLICO Trinidad, the government of Barbados intervened to provide liquidity to CLF's domestic subsidiaries. The central bank deposited US\$5 million into CLICO's mortgage subsidiary and provided access to a special credit window in the event that additional liquidity was needed. An oversight committee was set up to conduct the resolution process. So far, the mortgage line of business has been sold, and there have been negotiations to sell the general insurance business, but the life insurance company faces a significant shortfall estimated at about 3.3 percent of GDP on the basis of unaudited statements. In October 2010, the government requested the appointment of a judicial manager for BAICO Barbados and did the same for CLICO Barbados in December 2010.

- The Bahamas: In 2003, CLICO Bahamas, a subsidiary of CLICO Barbados with branches in Belize and Turks and Caicos, began making cash advances to its CLICO Enterprises Limited (CEL) subsidiary, primarily to finance a real estate project in Florida. CEL paid above-market interest rates to its parent company on the cash advances, with no fixed maturity. CLICO Bahamas was placed under provisional liquidation in February 2009 when it was unable to pay claims in Turks and Caicos. The judicial liquidator determined that it was unlikely CEL could repay the advances in full, leading to an estimated shortfall of about 0.2 percent of GDP as of end-June 2010. BAICO Bahamas raised funds in the ECCU also primarily to finance real estate projects in Florida. BAICO's ECCU operations were placed under judicial management in July-August 2009, and a judicial manager for BAICO Bahamas was appointed in September 2009. 
- ECCU: The flow of funds from the ECCU through BAICO Bahamas and CLICO Barbados prior to the crisis was largely in one direction - funds were taken in locally and the corresponding assets were for the most part held elsewhere. This left the region with the highest exposure - the liabilities of the two companies were nearly EC $\$ 2.1$ billion (17 percent of ECCU GDP). However, their assets in the ECCU were limited. Judicial managers found that BAICO had been insolvent since 1997. Trinidad and Tobago contributed US\$50 million through the Petroleum Fund toward the resolution of BAICO. CLICO Barbados operated in the ECCU through branches, and the key decisions will therefore be taken in Barbados.

- Guyana: Guyana's commissioner of insurance petitioned the Court to liquidate CLICO Guyana, which was the country's largest insurance company, the day after the decision to liquidate CLICO Bahamas, on which it had significant claims. The government has offered guarantees to policyholders (excluding life insurance products) up to G\$30 million (about US\$150,000) and to the National Insurance Scheme (with an exposure in the amount of 1.3 percent of GDP). Concerning life insurance policyholders, the government will facilitate (including using the residual cash in CLICO Guyana as collateral) the auctioning of the portfolio of performing life-insurance contracts. CLICO Guyana's capital shortfall is estimated to be 1.4-2.9 percent of GDP, depending on the extent to which assets can be recovered. Part of the losses would be covered by US\$15 million (0.7 percent of Guyana's GDP) from Trinidad and Tobago through the Petroleum Fund.

- Belize: CLICO Belize was placed under judicial management in April 2009 and into liquidation in September 2010. The life and health portfolio of the branch was transferred to a local insurance company in December 2009. The court approved a distribution of 25 percent of funds due to the annuity holders which was made in October 2010. The fixed assets of the company have not yet been disposed of.

- Suriname: Following a run by depositors and policyholders in July 2009, the Court approved a moratorium on payments by CLICO Suriname, a subsidiary of CLF. The authorities have facilitated the sale of CLICO Suriname to another local insurance company.

- Cayman Islands: The Cayman Islands branch of CLICO Trinidad was barred from writing new business in March 2009, and the branch closed in December 2009. 


\section{Policy Recommendations ${ }^{4}$}

\section{Strengthening the legal and regulatory framework to avoid a repeat of the} experience with CLF is clearly essential. Country experience shows that good supervision matters. For instance, the stronger framework Jamaica put in place after the crisis in the 1990s successfully insulated the country from the CLF crisis (see Appendix). In addition, in St. Lucia, the statutory fund deficits of CLICO and BAICO were significantly smaller than in other ECCU countries, reflecting a stronger supervisory regime. This section provides policy recommendations on strengthening the legal and regulatory framework.

\section{Principles for Effective Supervision}

\section{The quality of insurance sector supervision can be assessed against} internationally accepted established "core principles" (see Box 1). ${ }^{5}$ The supervision of nonbanks, including insurance companies, is not unlike the underlying principles for the supervision of commercial banks. The overarching criteria for effective supervision of nonbanks are similar to the regulatory powers expected in banking supervision:

- An effective legal framework;

- $\quad$ Rigorous licensing powers and powers to revoke a license;

- Powers of investigation such as on-site examinations, reporting, and off-site supervision; and

- Enforcement powers, including the power to request the subscription of additional capital.

20. Among these general principles of effective insurance supervision, the CLF collapse underscores the particular importance of several aspects given the crossborder nature of activities:

- Regional cooperation. Regulators can only get the complete picture of insurance companies operating in many jurisdictions through extensive sharing of information. To this end, the 30th CARICOM Meeting of Heads of State in July 2009 agreed to create a College of Regulators to share information regularly in order to address cross-border financial issues and to provide for consolidated supervision, both cross-border and crossfunctional. Plans are also underway to establish a regional regulatory framework.

\footnotetext{
${ }^{4}$ This section draws upon IMF (2010).

${ }^{5}$ International Association of Insurance Supervisors (2003).
} 


\section{Box 1. Core Principles for Effective Insurance Supervision}

According to the core principles established by the International Association of Insurance Supervisors, effective supervision of the insurance sector requires:

- An appropriate policy, institutional and legal framework;

- A supervisory authority with adequate powers, legal protection and financial resources; operational independence; adequate capacity; transparent operations; the ability to undertake group-wide supervision; and capacity for market analysis;

- Sharing of information with other supervisors domestically and abroad;

- Clear, objective and public licensing, with fit and proper owners, board members, and management;

- Supervisory authority to approve or reject significant changes in ownership, and a corporate governance framework recognizes and protects rights of all interested parties;

- Insurers with adequate internal controls, risk management, reinsurance, and tools to establish adequate premiums;

- Effective reporting, off-site monitoring, and on-site inspections;

- Preventive and corrective measures that are timely, suitable and necessary, and enforcement of corrective actions and sanctions;

- A range of options for orderly exit of insurers from the market;

- Adequate technical provisions;

- Investment standards including requirements on investment policy, asset mix, valuation, diversification, asset-liability matching, and risk management;

- Standards on the use of derivatives;

- Capital adequacy requirements with suitable forms of capital that enable the insurer to absorb significant unforeseen losses;

- Requirements for the conduct of intermediaries; and requirements for consumer protection, including timely, complete and relevant information to consumers both before and after a contract is signed;

- Disclosure of relevant information on a timely basis to stakeholders; and

- Measures to prevent, detect, and remedy insurance fraud and to deter, detect and report money laundering and the financing of terrorism.

- Trusteeship. An especially difficult aspect of the CLF experience is that liabilities and assets were in different jurisdictions. For this protection to be meaningful, assets should be under the control of trustee-for instance, a domestic commercial bank. 


\section{The Policy Agenda}

21. Building on the general principles outlined above, further work is needed to strengthen the regulatory framework in Trinidad and Tobago. In particular, new legislation and stronger supervisory personnel and procedures are needed to tackle problem companies. A new Insurance Act had been drafted by the time of the crisis after extensive consultation with the industry. The draft contains a modern approach to supervision, including measuring company solvency against a risk-based capital formula, strengthening corporate governance, and establishing more effective protection of policyholders. However, it has weaknesses and needs accompanying Guidelines. Although it would introduce riskbased supervision, it would still impose statutory fund requirements, which is a source of inconsistency in the insurance business. In addition, the draft law does not define the investment limits of statutory funds.

\section{Proposed regulatory changes, when enacted, should permit consolidated} supervision of internationally-active institutions and strengthen the present informal relationships with other foreign host regulators of the conglomerates' foreign banking entities. It will be important to implement new rules for the valuation of insurance liabilities and formulas for risk-based capital. More generally, market discipline over the activities of the large groups should be substantially improved by encouraging them to disclose more than pro-forma information in their published reports, particularly in relation to credit and market risk management policies and actual positions, and average levels of connected exposures during the reporting period.

\section{Identification of possible system-wide spillovers arising from problems within} the large financial groups should be a key part of a risk-based approach to consolidated supervision. Part of this process could involve stylized stress-tests of the portfolios and counterparty risk management practices of individual large institutions and identifying the most vulnerable channels for contagion. It is likely to involve a mix of quantitative and qualitative analysis. The results should be discussed with institutions and appropriate mitigation measures put in place where necessary.

\section{Conclusion}

\section{The collapse of CLF has had a devastating impact on much of the Caribbean,} and has been costly to governments, public and private pension schemes, bank and nonbank financial institutions, and individuals. The cost could be as high as 10 percent of GDP in Trinidad and Tobago and 17 percent of GDP in the ECCU. The resolution of the crisis is nearly complete in countries with smaller exposures, and is taking some time in those with larger exposures. 
25. The causes of the crisis were rapid growth in illiquid assets through connected exposures financed by comparatively liquid liabilities. The inadequate legal and supervisory framework provided supervisors with weak authority to address these issues.

26. This paper has provided an overview of why the crisis occurred and some suggestions on how to prevent future crises. It is hoped that it will assist authorities in addressing the significant remaining challenges, including completing crisis resolution efforts and strengthening the regulatory framework. 


\section{ApPendix: Parallels With Previous Insurance CRises}

The collapse of CLF differs from previous insurance sector crises in the extent to which it crossed jurisdictional boundaries to affect a large number of countries. However, there are many parallels with previous crises which provide a useful context for understanding why CLF collapsed and how to avoid a future crisis.

\section{A. Jamaica}

Insurance companies played a key role in triggering the second stage of the Jamaican financial sector crisis during the late 1990s. Life insurance companies offered new insurance products, known as investment or lump-sum policies, which enabled them to take deposits disguised as insurance premia. Only a small portion of deposits went toward insurance coverage, while the majority was used to invest in real estate, stocks, bonds, and securities. The interest paid was unrelated to the performance of insurance company assets. Rising interest rates brought the maturity mismatch of assets and liabilities into the open, as insurance companies borrowed from connected banks.

During 1996, a group of chief executive officers of life insurance companies approached the government for help with what they described as liquidity problems. Further examination revealed that there was in fact an insolvency problem to various degrees, and, moreover, that the banking sector was also affected through linkages within conglomerates. Almost 500,000 policyholders and over 2 million depositors were at risk. The government announced that it would bear the losses of covering the total exposure of depositors, life insurance policyholders, and pensioners. The bailout of the banking and insurance sectors led to a partial nationalization of the domestically-owned financial sector at a cost of over 40 percent of GDP.

The government established a new institution in 1997, the Financial Sector Adjustment Company (FINSAC), which had the objective of restructuring, merging, and recapitalizing financial institutions. FINSAC took ownership stakes in five commercial banks, seven insurance companies, three building societies, and three investment banks. In each case, FINSAC purchased ownership stakes of at least 25 percent to obtain veto power over management decisions, and in some cases FINSAC took over management of the institutions.

The government also pushed through a number of reforms to strengthen financial sector supervision. These led to the establishment of the Financial Services Commission in 2001. Apparently as a result of these reforms, CLICO and BAICO chose not to operate in Jamaica, which was therefore unaffected by the CLF crisis. 


\section{B. Republic of Korea}

During 1997, the Republic of Korea faced a systemic collapse of its financial sector not limited to insurance. Eighteen life insurers were deemed to be insolvent by the end of 1997. Both life and non life insurers had been encouraged to become shadow banks, partly to fund their chaebol parents. The Asian financial crisis then exposed the chaebol balance sheets and those of their creditors, a number of which had also engaged in risky real estate investments.

\section{The Financial Supervisory Commission asked all insolvent insurers to submit} rehabilitation plans. Following plan submission, four life insurers immediately had their policy books transferred to other large insurers. Subsequently, another five troubled insurers were merged into other insurers, and another was resolved through portfolio transfer. Other insurers were placed in the hands of legal custodians and put up for sale.

These enforcement actions were funded by issuance of specialized bonds, public reserve funds and borrowing from the World Bank. The insurance sector received 12.6 trillion won from the government to protect policyholders, which was used to fill the asset liability gap and where necessary to acquire troubled insurers. The key principles adopted in this resolution program were: minimize the fiscal impact; ensure speedy resolution of troubled insurers; pursue regulatory reform in a transparent manner; and improve corporate governance. A key regulatory outcome was that insurers have to now submit their solvency position on a quarterly basis.

\section{Canada}

Confederation Life of Canada (Confed) entered liquidation in August 1994, following large losses in its real estate and mortgage portfolio. Confed was a life insurance company with 1.8 million Canadian policyholders with operations also in the United States and the United Kingdom. At the end of 1993, 71 percent of its assets of US\$14 billion were in real estate and mortgages.

There were failed rescue attempts by another company in 1993 and by the six leading Canadian life insurers in 1994. Regulators became concerned that public apprehension over the company could lead to wave of withdrawals and cancellations, with potential systemic risks. The liquidator ultimately determined that the company was not in fact insolvent. There were no losses to policy holders, and the cost to the industry-financed compensation fund was only Can $\$ 5$ million. 


\section{References}

International Association of Insurance Supervisors, 2003, Insurance Core Principles and Methodology, (Basel: International Association of Insurance Supervisors).

International Monetary Fund, 2006, Trinidad and Tobago: Financial System Stability Assessment, including Reports on the Observance of Standards and Codes, (Washington DC: International Monetary Fund).

International Monetary Fund, 2010, Trinidad and Tobago: Financial System Stability Assessment, (Washington DC: International Monetary Fund). 


\section{Monetary Policy In TRINIDAD AND TOBago ${ }^{1}$}

\section{A. Introduction}

1. Monetary policy in Trinidad and Tobago is constrained by the weak monetary transmission mechanism and the de facto fixed exchange rate regime. ${ }^{2}$ This chapter seeks to shed light through quantitative analysis on the reasons for the weak transmission mechanism, in particular the effectiveness of repo rate, now the primary monetary policy tool. The chapter is organized as follows: Section B discusses the objectives, instruments, and constraints for monetary policy; Section $\mathrm{C}$ describes recent monetary developments; and Section D examines the monetary policy mechanism, in particular, the effectiveness of changes in the repo rate and the inter-linkages between various economic variables. Section E concludes with recommendations for making the repo rate a more effective instrument. An Appendix presents the details of the quantitative analysis.

\section{B. Objectives, Instruments, and Constraints for Monetary Policy}

2. The official monetary policy objectives of the Central Bank of Trinidad and Tobago (CBTT) are to maintain a low rate of inflation, an orderly foreign exchange market, and an adequate level of foreign exchange reserves. ${ }^{3}$ At the same time, evidence suggests that the CBTT also seeks to support growth in the time of weak economic activity. ${ }^{4}$

\section{The main instruments of monetary} policy are the reserve requirement, open market operations, and the repo rate.

\section{- $\quad$ Reserve requirement. The CBTT has}

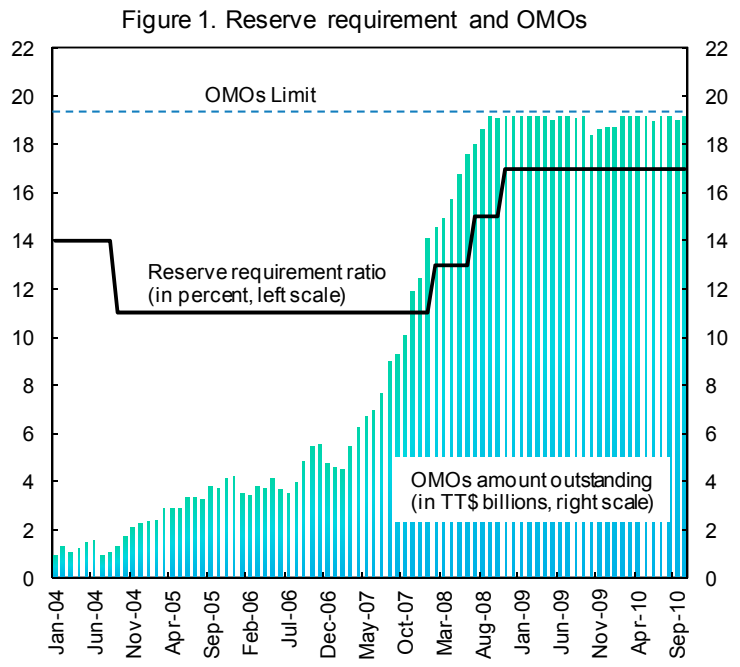

\footnotetext{
${ }^{1}$ This chapter was prepared by Yi Wu. Data are from International Financial Statistics and the central banks of Trinidad and Tobago, Barbados and The Bahamas. The author is grateful to Central Bank staff including Daryl Cheong, Carlene Coker, Wendy D'arbasie, Shanta Dhoray-Baig, Angela Henry, Susan Ramirez, Avinash Ramlogan, and Veronica Ramcharan for providing data and clarification; to Judith Gold, Philip Liu, and Hunter Monroe for valuable comments and suggestions; to Lulu Shui and Genevieve Lindow for excellent research assistance; and to Eneshi Kapijimpanga and Sherrie Barnes for their assistance in preparing the manuscript.

${ }^{2}$ See also the discussions in IMF $(2004,2006)$ of the transmission mechanism in Trinidad and Tobago.

${ }^{3}$ See http://www.central-bank.org.tt/monetary_policy/index.php?pid=2001.

${ }^{4}$ For example, a November 2010 press release indicated that the decision to lower of the repo rate was made to "provide further stimulus to domestic demand and private investment."
} 
reduced its reliance on the reserve requirement as a major tool of monetary policy and last changed it (to 17 percent) in November 2008 (Figure 1). ${ }^{5}$ The required and excess reserves are unremunerated, but the CBTT has also been using interest-bearing deposits at the CBTT to absorb excess liquidity.

- $\quad$ Open market operations (OMOs). The secondary market for government securities is thin as buyers (banks and nonbank financial institutions) usually hold securities to maturity. ${ }^{6}$ As a result, OMOs have been mostly used for mopping up liquidity. There is a legal limit of TT\$15 billion for T-bill issuance, of which TT $\$ 800$ million is intended for deficit financing and TT\$14.2 billion for sterilization. There is also a TT\$ 5 billion limit on Treasury notes, which are entirely for sterilization purposes. Treasury bills and notes for OMOs reached the limit in the third quarter of 2008 (Figure 1). The Treasury Bonds Act of 2008 allows the issuance of Treasury bonds for the purpose of liquidity management (where there are no specified limits), but none have been issued since July 2008. ${ }^{7}$ In addition, the CBTT has not issued any central bank bills since November 2008.

- $\quad$ The repo rate. The repo rate was introduced as a monetary policy instrument in May 2002, and has since become the principal instrument used by the CBTT to influence market interest rates. It is the rate at which the CBTT provides overnight financing to commercial banks that are temporarily unable to meet their liquidity requirements. There are no liquidity operations associated with changes in the repo rate.

\section{The de facto exchange rate peg limits the scope of monetary policy although the} CBTT still maintains some policy flexibility. There are no formal exchange controls; nevertheless, the CBTT has some flexibility in setting the policy repo rate as a result of country-specific features. The repo rates do not affect the foreign exchange (FX) market directly as there are no liquidity operations associated with repo rate changes. Therefore, the repo rate affects the FX market mostly through its impact on deposit rate, where the impact is limited and gradual (see the analysis below). ${ }^{8}$ The additional FX demand resulting from a repo rate reduction could be managed by FX sales by the CBTT. This would reduce liquidity

\footnotetext{
${ }^{5}$ There is no reserve requirement for foreign currency deposits.

${ }^{6}$ Commercial banks held 44 percent of total Treasury bills and notes outstanding as of end-October 2010, up from 15 percent in January 2009. Treasury bills and notes accounted for 7.5 percent of banks' total assets in June 2010, up from 3.6 percent in January 2009.

${ }^{7}$ In principle, short-term government securities would be more preferable for liquidity management.

${ }^{8}$ In the current circumstances, where the deposit rate is already extremely low ( 0.3 percent $)$, the impact would probably be limited. The pressure on the FX market would be higher if there were associated liquidity injections.
} 
but still allow for some positive impact on credit growth from the repo rate reductions, especially in the current environment of excess liquidity.

\section{Monetary Developments}

5. The monetary policy stance has shifted from restrictive during 2006-08 to accommodative while liquidity rose dramatically. Inflation was the dominant concern during 2006-08, and monetary policy in that period was broadly restrictive as reflected by repo rate and reserve requirement ratio hikes and OMOs. Monetary policy (repo rate) became accommodative in early 2009 with the economic slowdown and a moderation of inflation, but a resurgence of inflation in 2010, largely driven by increasing food prices, halted further easing until August 2010. During this time, weak credit growth combined with net fiscal injections and conversion from investments to bank deposits ${ }^{9}$ substantially increased excess liquidity (Figure 2). Excess reserves drove down the interest rate on 30-day T-bills from 6.9 percent at end-2008 to 0.3 percent in November 2010. To reduce excess liquidity, the CBTT required commercial banks to make deposits in interest-bearing accounts in the CBTT (currently totaling TT $\$ 4.5$ billion with maturity of 12 or 18 months).

\section{The CBTT lowered the repo rate by a} total of 500 basis points (bps) from March 2009 to November 2010, but the reduction in actual lending rates has been much more moderate (Figure 3). While commercial banks lowered the prime lending rate in step by a total of $425 \mathrm{bps}$, the actual lowest rate banks offered to customers on new demand loans, for example, was only reduced by $263 \mathrm{bps}$ from March 2009 to September 2010. During the same period, banks lowered the deposit rate from 1.3 percent to 0.3 percent.

\footnotetext{
${ }^{9}$ In late 2009, a major mutual fund converted its funds from fixed net asset value (NAV) to floating NAV, triggering a large withdrawal and a substantial increase in bank deposits.
}

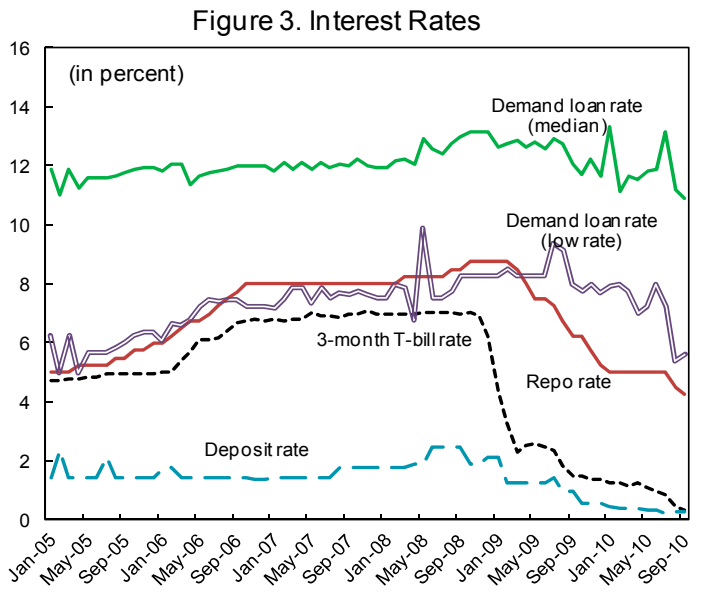


7. Despite the repo rate reductions, credit market activity has remained weak and private sector credit continued to fall (Figure 4). This reflects the still weak recovery in the non-energy sector in addition to the moderate reductions in actual lending rates. Home mortgage loans were the only loan category that had robust growth. Nevertheless, banks have remained profitable. Return on equity declined from 25.9 percent in 2008 to 20.2 percent in 2009 and to 18.6 percent in September 2010. A major contributor to profits has been an increase in the already high interest

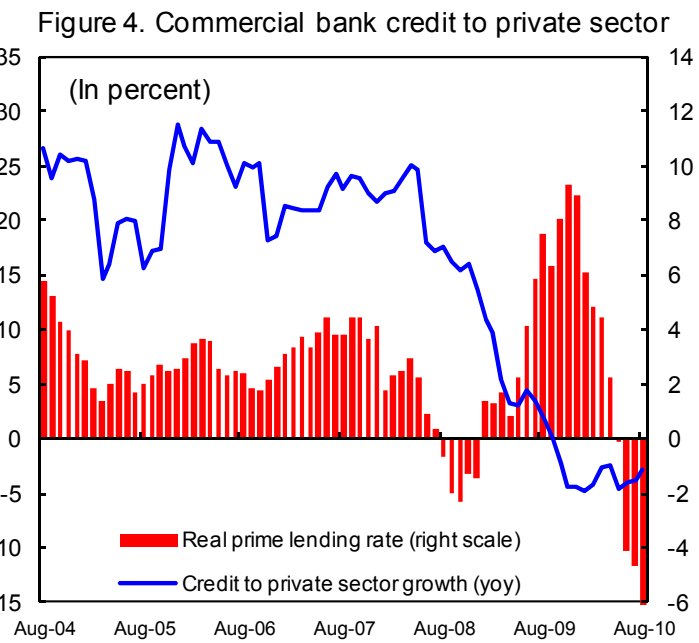
spread, from 8.3 percent in 2008 to 10.1 percent in 2009 , and declining slightly to 9.3 in September 2010. The ratio of the interest margin to gross income increased from 65.2 percent in 2008 to 67.5 in September 2010.

\section{There has also been a marked increase in the queues to purchase foreign} exchange (Figure 2). The buildup in queues followed the increase in excess liquidity, although the weakening in the balance of payments following declining energy prices (especially in 2009) was also an important factor. The CBTT substantially increased its FX sales in 2009/10 and eliminated the queues as of end-November 2010.

9. The recent monetary developments raise a number of questions. These include:

- Why have the repo rate reductions and the high excess reserves not led to larger declines in lending rates?

- Would credit growth have been even weaker without the rate reductions?

- How were banks able to maintain high interest spreads amid high excess liquidity?

The next section seeks to answer these questions while assessing the effectiveness of the repo rate in affecting credit and other economic variables.

\section{Effectiveness of the Repo Rate as a Monetary Policy Instrument}

\section{This section examines how effective the repo rate is in affecting market interest} rates, credit growth, inflation, and queues. We focus on the period between June 2005 and September 2010 because of data limitations. This is also the period of most active repo rate movements. The sample can be divided into three distinct sub-periods: the period of rising repo rates from June 2005 to October 2006, when the repo rate was increased by 275 bps; the period of broadly stable repo rates from October 2006 to February 2009, when the repo rate 
was raised by $75 \mathrm{bps}$; and the period of repo rate reductions from February 2009 to September 2010, when the repo rate was reduced by 450 bps.

11. The analysis below uses Vector Autoregression (VAR) impulse response analysis to capture the dynamic impact of a one standard deviation shock to one variable on another variable, such as the impact of a repo rate change on lending rates. The results are summarized in Table 1 and described below; technical details are set forth in the Appendix. It should be noted that quantitative results presented below need to be interpreted with caution, given the relatively short time horizon, data measurement issues, and possible asymmetry of the relationship (as discussed below).

Table 1. Impulse Responses from VAR analyses

\begin{tabular}{|c|c|c|c|c|c|}
\hline Shocked Variable & $\begin{array}{l}\text { One standard } \\
\text { deviation increase }\end{array}$ & Response Variable & Response & Time & $\begin{array}{l}\text { Significant at } \\
95 \text { percent? }\end{array}$ \\
\hline Repo rate & $17.5 \mathrm{bps}$ & Lending rate & $5.5 \mathrm{bps}$ & 3 months & Yes \\
\hline Excess reserves & TT\$660 million & Lending rate & -3.4 bps & 6 months & No \\
\hline Non-oil output & 4 percent & Non-mortage credit & 0.7 percent & One quarter & Yes \\
\hline Prime rate & 174 bps & Non-mortage credit & 1 percent & One year & No \\
\hline Repo rate & $15.5 \mathrm{bps}$ & Deposit rate & $5.5 \mathrm{bps}$ & 6 months & Yes \\
\hline Excess reserves & TT\$640 million & Deposit rate & -7.5 bps & 3 months & Yes \\
\hline Repo rate & & $\mathrm{T}$ bill rate & Nil & 3 months & No \\
\hline Excess reserves & TT\$600 million & $\mathrm{T}$ bill rate & -19 bps & 3 months & Yes \\
\hline Repo rate & $17.5 \mathrm{bps}$ & Inflation & Nil & 3 months & No \\
\hline $\mathrm{T}$ bill rate & 34 bps & Queues & -US\$10 million & 2 months & Yes \\
\hline Deposit rate & $30 \mathrm{bps}$ & Queues & -US\$9.4 million & 2 months & Yes \\
\hline Repo rate & 26 bps & Queues & -US\$5.4 million & 3 months & Yes \\
\hline Excess reserves & TT\$670 million & Queues & US $\$ 11$ million & 2 months & Yes \\
\hline
\end{tabular}

Source: Fund staff estimates.

\section{Lending Rate}

\section{Lending rates respond more to the repo rate than to excess reserves, but the} impact is moderate. Granger causality tests indicate that the repo rate helps forecast the lending rate. ${ }^{10}$ In contrast, there is little evidence that excess reserves help forecast the lending rate. This is also consistent with the results from a VAR analysis using lending and repo rates and excess reserves, which allows interactions among the three variables. VAR analysis shows that a shock increasing the repo rate by one standard deviation (17.5 bps)

\footnotetext{
${ }^{10}$ A bivariate Granger causality test examines whether variable $y$ helps forecast another variable $x$ once lags of $x$ are controlled for. The reasoning is that if event $\mathrm{Y}$ is the cause of event $\mathrm{X}$, then the event $\mathrm{Y}$ should precede the event X.
} 
would lead to a moderate $5.5 \mathrm{bps}$ increase in the lending rate by the third month (Appendix Figure 1). A TT $\$ 660$ million increase in excess reserves would only lead to a decline in the lending rate by $3.4 \mathrm{bps}$ by the sixth month, and the impact is not significant statistically.

13. The repo rate affects the lending rate more through signaling rather than through the market channel. The current high liquidity makes the repo rate nonbinding, as banks have not tapped the repo window since February 2009 (Figure 5). Lending rates also seem to be more responsive to repo rate increases than cuts: lending rates were raised by 280 bps during July 2005 to February 2009

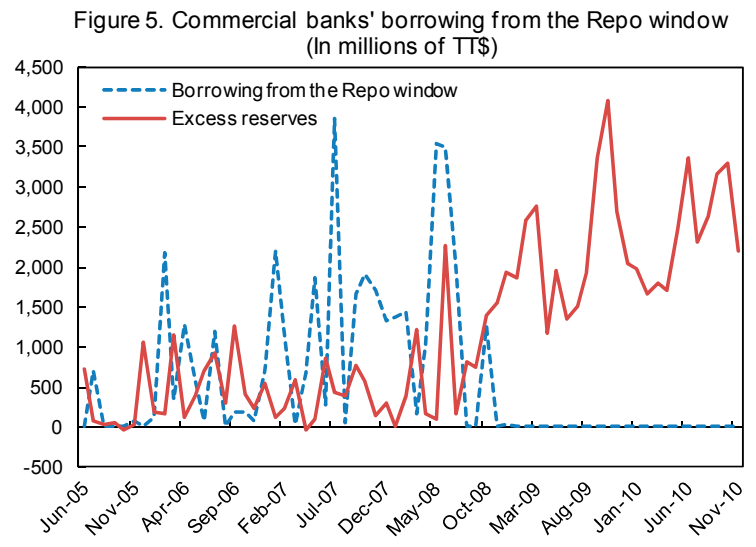
when the repo rate was raised by 350 bps, but were only cut by 288 bps during March 2009 to September 2010 when the repo rate was cut by 450 bps. However, this may also reflect the lower excess liquidity in the first period which may have made the repo rate more binding.

\section{The weak impact of excess reserves on the lending rate could be related to the} market structure. The small number of commercial banks (eight) probably implies limited competitive pressures on banks to lower the lending rate under excess liquidity. The interest spread, 9.3 percent at end-September, is high by international standards (Figure 6). One piece of evidence of banks' pricing power is that the interest rate spread seems to be mostly responsive to the reserve requirement ratio (Figure 7), suggesting that banks seem to have been able to pass on higher costs as a result of higher reserve requirement to customers.
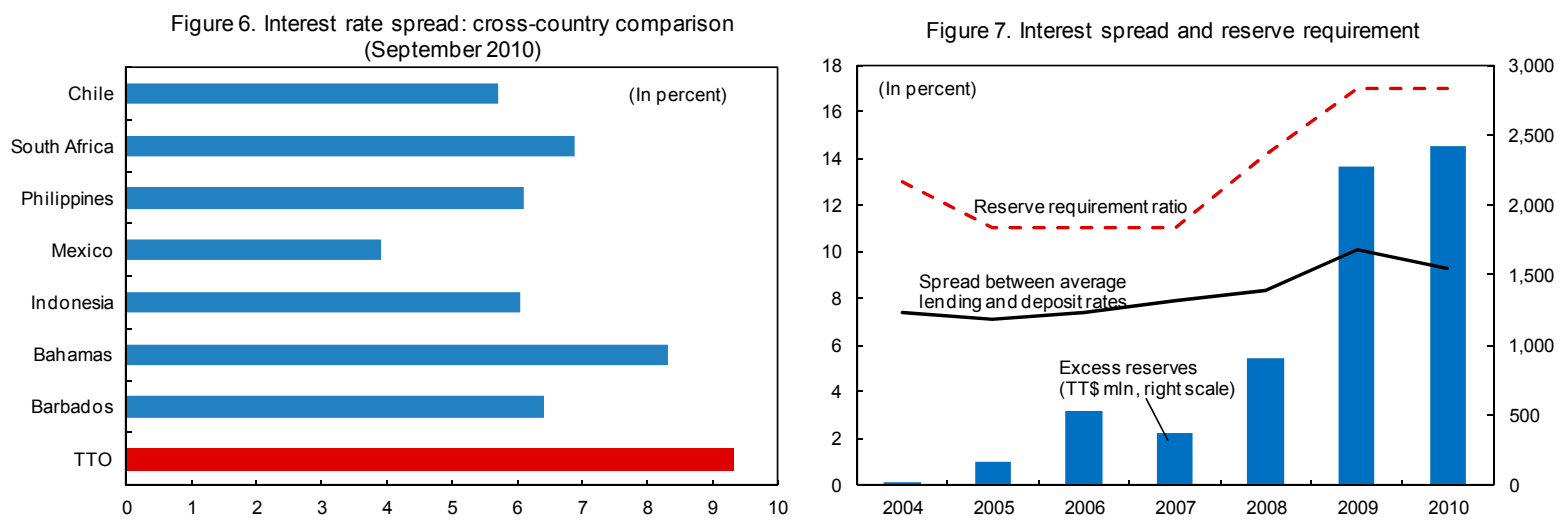

\section{Credit Growth}

15. Private credit does not seem to be responsive to interest rates when controlling for economic activity. Private sector credit growth has been declining since October 2009 despite the rate reductions, although the credit decline may have been even larger without the rate reductions. Controlling for the economic conditions, private sector credit remains 
unresponsive to interest rates. VAR analysis shows that a shock increasing non-oil output by one standard deviation ( 4 percent) would lead to 0.7 percent growth in non-mortgage credit in the first quarter, and 1.7 percent growth in two quarters (Appendix Figure 2). By contrast, a $174 \mathrm{bps}$ increase in the prime lending rate will only reduce credit by 1 percent in one year, and the impact is not statistically significant.

\section{Deposit Rate}

16. Both the repo rate and excess reserves seem to affect deposit rates. Granger causality tests indicate that the repo rate and excess reserves help forecast the deposit rates. Deposit rates seem to be more responsive to repo rate cuts than increases: they were raised by 33 bps during January 2005 to February 2008 when the repo rate was raised by 300 bps, but were cut by 183 bps from January to September 2009 when the repo rate was cut by 450 bps, although high excess reserves in the latter period could have been a factor. VAR analysis shows that a shock increasing the repo rate by one standard deviation (15.5 bps) would lead to a 5.5 bps increase in deposit rates in six months (Appendix Figure 3). By comparison, a one standard deviation shock that increased excess reserves by TT $\$ 640$ million would push down the deposit rate by 7.5 bps by the third month and 12.5 bps in 6 months.

\section{T-bill Rate}

17. The low T-bill rates reflect primarily excess liquidity rather than the repo rate. Although the repo rate could have some impact on the T-bill rate through its impact on the deposit rate or liquidity, there is little evidence that the repo rate helps forecast T-bill rates. A Granger causality test confirms that excess liquidity helps forecast T-bill rates as expected. We next conduct a VAR analysis using the T-bill and repo rates and excess reserves. We also include the U.S. T-bill rate as an exogenous variable in the VAR analysis. A shock increasing excess reserves by one standard deviation (TT $\$ 600$ million) would drive down T-bill rates by 19 bps by the third month, and by 24 bps by the fifth month (Appendix Figure 4). The impact of the repo rate on the T-bill rate is very small and statistically insignificant.

\section{Inflation}

18. The repo rate seems to have a limited impact on inflation reflecting the weak impact of the repo rate on credit growth. Another channel through which the repo rate could affect inflation is through inflation expectations, as people may link the monetary policy stance of the CBTT to inflation outcomes. However, a Granger causality test indicates that the repo rate does not help forecast inflation. VAR impulse responses show that a repo rate hike has no statistically significant impact on inflation and does not lead to reductions in inflation (Appendix Figure 5). The finding that the repo rate seems to have little impact on inflation is robust to different specifications (see the Appendix for more details). 


\section{FX Queues}

19. Both T-bills and deposit rates seem to affect FX queues. Granger causality tests indicate that the spreads between T-bill and deposit rates (the two rates have a correlation of 0.86) and the U.S. T-bill rate respectively help forecast the queues. A lower interest spread with the U.S. rate provides incentives for depositors and investors to switch into the U.S. dollar, increasing FX demand. The VAR impulse responses indicate that a 34 bps increase in the T-bill rate reduces queues by US\$10 million in 2 months (Appendix Figure 7). Similarly, a 30 bps increase in the deposit rate reduces the queues by US\$9.4 million in 2 months (Appendix Figure 8).

20. The repo rate also seems to have some moderate impact on queues. One channel through which the repo rate could affect queues is through its impact on deposit rates. However, a Granger causality test shows that the repo rate to U.S. T-bill rate spread does not help predict queues. On the other hand, the VAR impulse response suggest that a $26 \mathrm{bps}$ increase in repo rate could lead to a US\$5.4 million decline in queues by the third month (Appendix Figure 9). The results including inflation rates again are broadly similar.

21. Excess reserves are an important factor affecting queues. Figure 4 suggests that excess reserves led to higher queues, which led to higher CBTT FX sales. A Granger causality test confirms that excess reserves help forecast queues. Excess reserves could affect queues through their impact on both the T-bill and deposit rates. VAR impulse responses suggest that a TT\$670 million increase in excess reserves would lead to an US\$11 million increase in queues by the second month (Appendix Figure 10). A Granger causality test also confirms that excess reserves help predict CBTT FX interventions.

\section{E. Concluding Remarks}

22. Our analysis confirms that the monetary transmission mechanism appears to be weak. Despite the de facto exchange rate peg, the CBTT has some flexibility in setting the policy repo rate because of the weak pass-through of the repo rate to deposit and T-bill rates, and the lack of associated liquidity operations with repo rate changes as these factors limit the repo rate's impact on the FX demand. At the same time, the repo rate does not seem to be an effective monetary policy instrument, since its impact on the lending rate is moderate, reflecting, in part, the high level of excess reserves. In addition, lending rates' effect on credit growth is also limited, especially in the current downturn. Furthermore, the repo rate does not seem to have a strong impact on inflation. This is related to its weak impact on credit growth, but is also because of the lack of liquidity operations associated with repo rate changes. This suggests that the CBTT may need to rely more on liquidity operations to fight inflation.

\section{The monetary transmission mechanism could be strengthened by stronger} management of excess liquidity and other measures. Excess reserves not only weaken the 
repo rate's impact on market interest rates but also add to pressures on the FX market. The authorities could seek to increase government securities allocated for OMOs to help manage liquidity. In the interim, the CBTT could also consider using central bank bills or additional interest-bearing deposits at the CBTT to manage excess liquidity. The strength of the CBTT's balance sheet implies that interest costs should not be a significant constraint on monetary policy decisions. Another option to make the repo rate more effective in affecting lending rates could be to pay interest on excess reserves deposited at the central bank. 


\begin{abstract}
APPENDiX
This appendix provides more detail on the quantitative analysis described above. It discusses in more detail the data used, the statistical test results, and their robustness. It also presents impulse response charts, showing the response over time of each variable to shocks to other variables. Significance refers to the 5 percent level if not indicated.
\end{abstract}

\title{
Lending Rate
}

The lending rates used in the analysis are the lowest rates that customers received for demand loans. Rates for the median loan rate and for other types of loans follow similar trends. Weighted rates on new loans would be the ideal lending rate for the analysis; however, the data are not available. We use monthly data from June 2005 to September 2010. The null hypothesis of no Granger causality can be rejected at the 5 percent level. We use the level instead of the log of excess reserves because of the existence of a few negative observations. The default lag for all the analyses is 2 .

The null hypothesis of a unit root for the lending rate can be rejected at 5 percent level using the augmented Dickey-Fuller test. The null however cannot be rejected for the repo rate, and the deposit and T-bill rates that are discussed below. This is probably the result of high persistence in the rates, short data period, and the low power of the test.

\section{Credit Growth}

Our measure of credit growth is non-mortgage credit since mortgage credit seems to have different dynamics. For example, from January 1994 to November 2003, mortgage loans declined by 36 percent while credit to the private sector excluding mortgage grew by 149 percent. In addition, it is not possible to control for housing prices as data are not available. We use quarterly data from 1997Q3 to 2010Q2 on banking sector's non-mortgage credit to the private sector in nominal TT\$ (in log), non-oil GDP in TT\$ (in log), and the real prime lending rate.

The prime lending rate instead of the actual lending rate is used because of data limitations over the longer period, and the correlation between the prime lending rate and the lowest demand loan rate for the overlapping period is $\mathbf{0 . 8 8}$. Quarterly non-oil nominal GDP is constructed using the quarterly real non-oil GDP growth from the central bank and CPI inflation, and the real lending rate is calculated as nominal rates minus y-o-y inflation. We use non-oil GDP because loans to the energy sector account for less than 4 percent of total loans. Although the null hypothesis of a unit root cannot be rejected for nonmortgage credit and GDP, the hypothesis of no cointegration can be rejected at 5 percent level.

\section{Deposit and T-bill Rates}

The null hypothesis of no cointegration for the VAR variables can be rejected at 10 percent and 5 percent respectively. 


\section{Inflation}

The VAR analysis uses monthly data from May 2002 to October 2010 and includes headline inflation (yoy) and the repo rate. We also include the oil and gas price changes (yoy) as proxies for the domestic economic activity and international food price inflation, all as exogenous variables (all helps forecast domestic inflation). In an alternative specification, we also add private sector growth as a proxy for economic activity and the results (not reported) are similar.

Since there are potential large measurement errors in the inflation data, especially for food products, we also use core inflation for the analysis. ${ }^{11}$ The repo rate again does not help forecast core inflation, and the VAR impulse response show that a $15 \mathrm{bps}$ increase in the repo rate could lead to a very small ( 0.03 percent) decline in core inflation in the second month, but the impact is not statistically significant (Figure 6). We conduct similar analysis using quarterly data covering the same period, where we use the non-energy sector GDP growth as a measure of economic activity. The results (not reported) again point to little impact on inflation from the repo rate.

\section{FX Queues}

We use monthly data from January 2006 to November 2010, and oil and gas prices (in log) as exogenous variables to control for FX supplies. We use the level instead of the log of queues because the existence of zero values. Although the null hypothesis of a unit root cannot be rejected for queues, the null hypothesis of no cointegration can be rejected, including for the subsequent analyses involving the T-bill rates and excess reserves. We also conduct similar analyses adding inflation rate (either headline or core) to the VAR. The results (not reported) are broadly similar, and the inflation does not have a statistically significant impact on the queues.

\footnotetext{
${ }^{11}$ See the accompanying Article IV Consultation staff report for more details.
} 
Figure 1. Repo rate, excess reserve, and lending rate Response to Cholesky One S.D. Innov ations \pm 2 S.E.
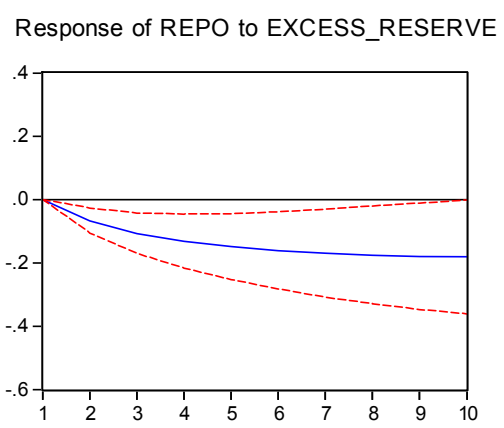

Response of EXCESS_RESERVE to EXCESS_RESERVE

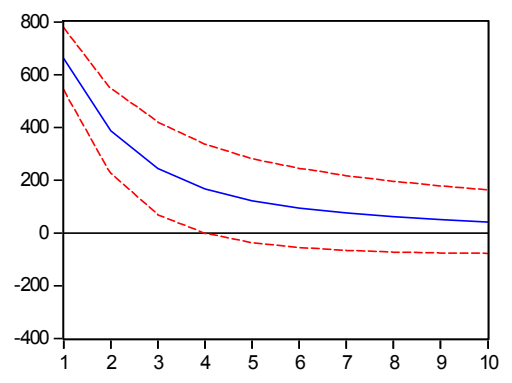

Response of LENDING_RATE_LOW to EXCESS_RESERVE

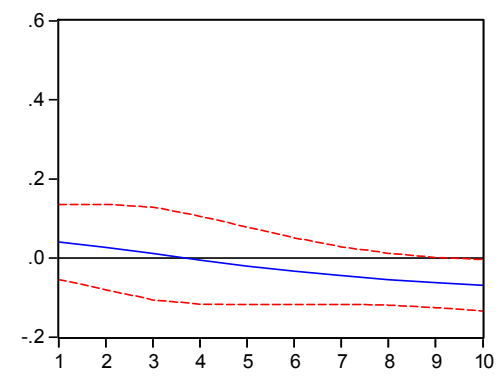

Response of REPO to LENDING_RATE_LOW

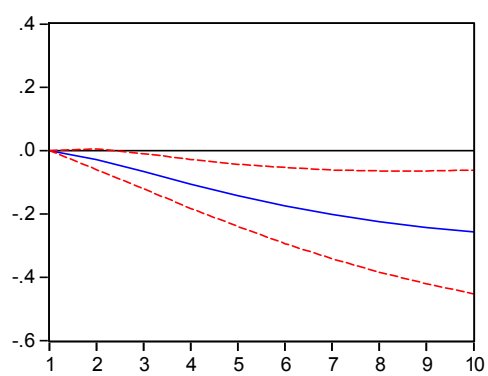

Response of EXCESS_RESERVE to LENDING_RATE_LOW

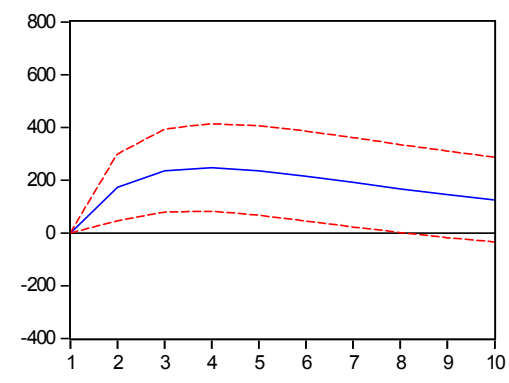

Response of LENDING_RATE_LOW to LENDING_RATE_LOW

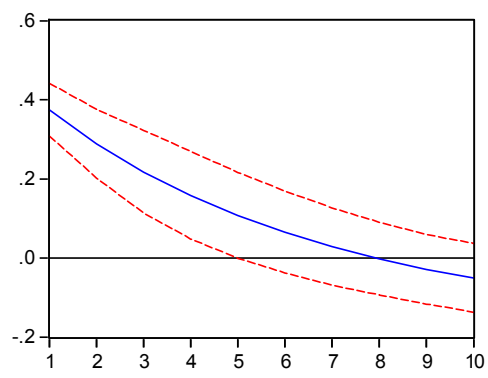

Response of LENDING_RATE_LOW to REPO

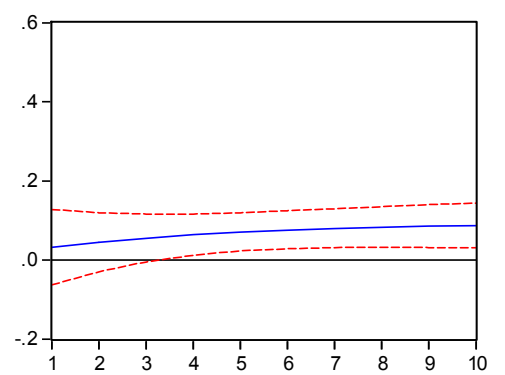

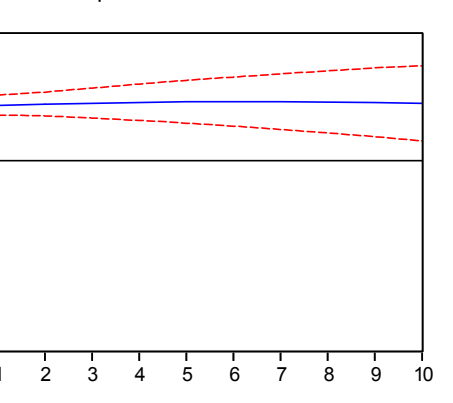

Response of EXCESS_RESERVE to REPO

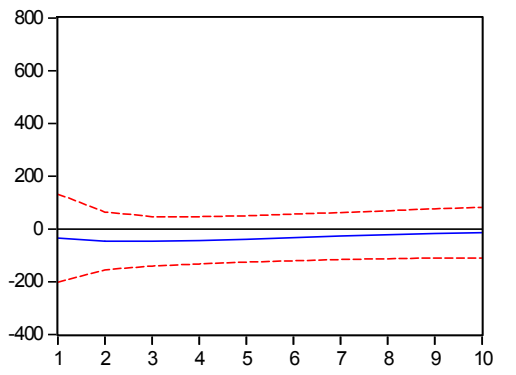


Response of LGDPNONOIL to LGDPNONOIL

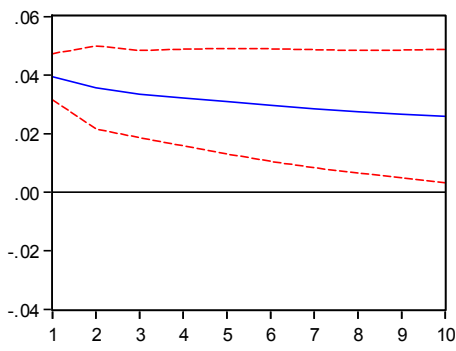

Response of RRATE to LGDPNONOIL

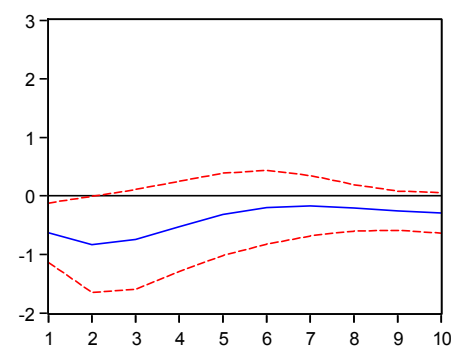

Response of LCREDITEXCMORT GAGE to LGDPNONOIL

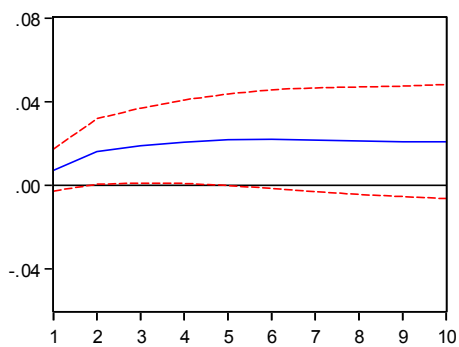

Figure 2 Output interest rate, and credit Response to Cholesky One S.D. Innovations \pm 2 S.E.

Response of LGDPNONOIL to RRATE

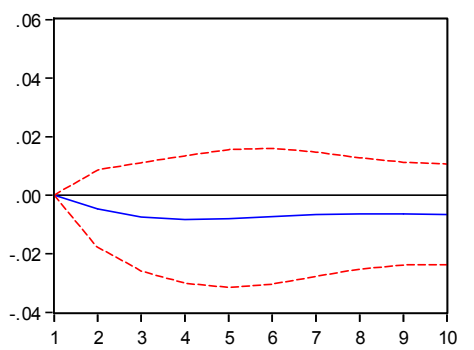

Response of RRATE to RRATE

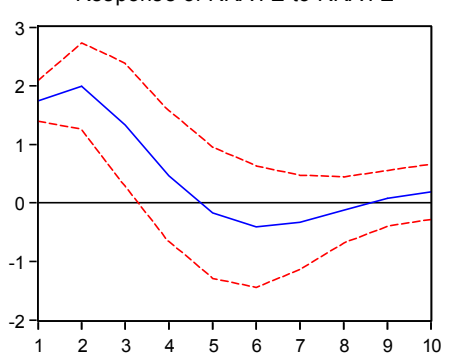

Response of LCREDITEXCMORTGAGE to RRATE

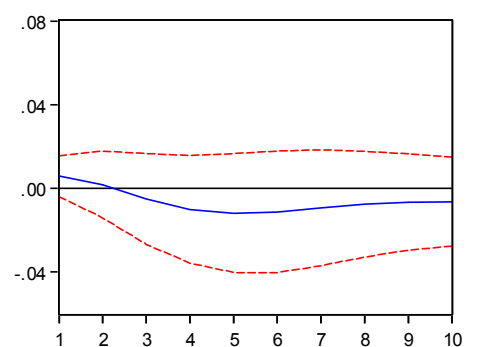

Response of LGDPNONOIL to LCREDITEXCMORTGAGE

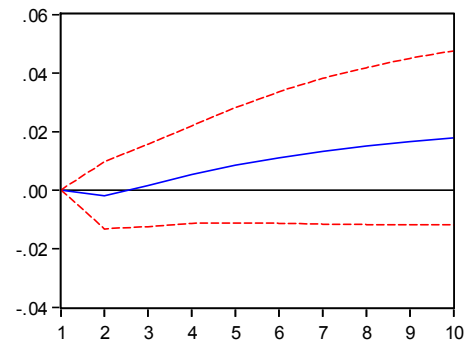

Response of RRATE to LCREDITEXCMORTGAGE

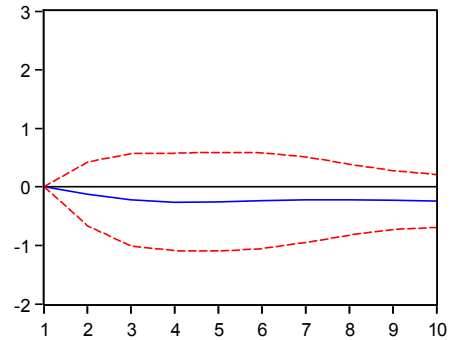

Response of LCREDITEXCMORTGAGE to LCREDITEXCMORTGAGE

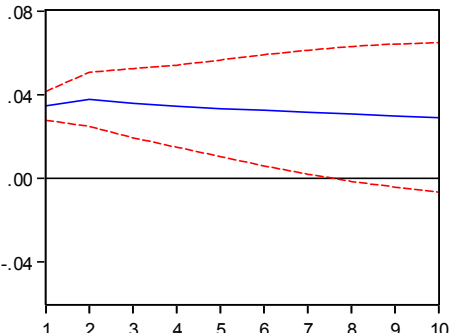




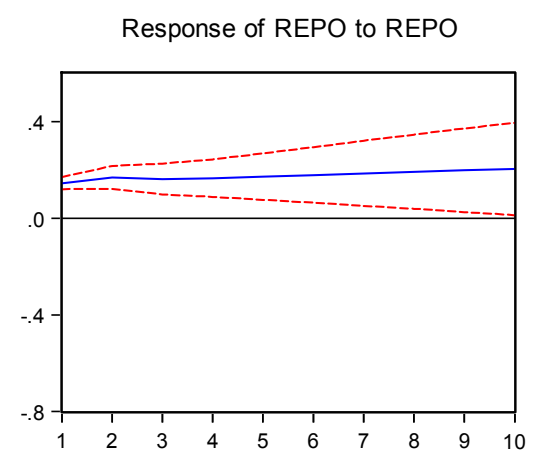

Response of EXCESS_RESERVE to REPO

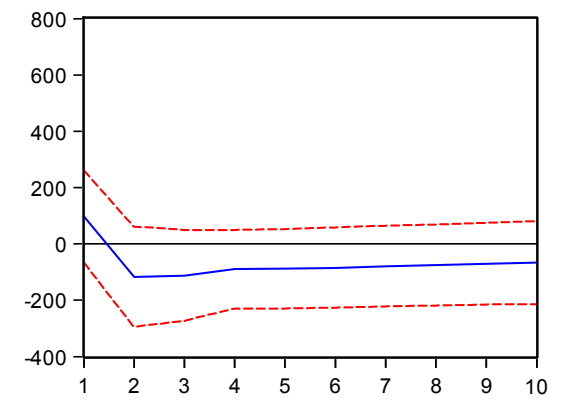

Response of DEPOSITRATE to REPO

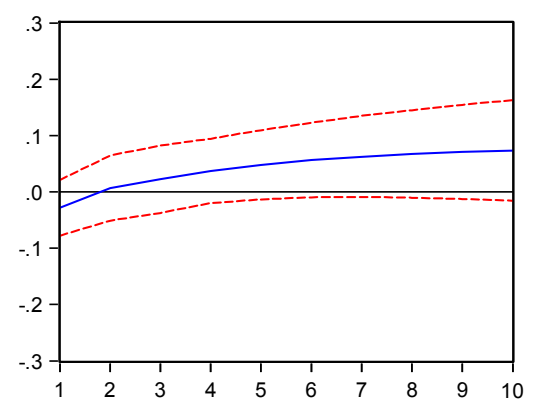

Figure 3. Repo rate, excess reserve, and deposit rate Response to Cholesky One S.D. Innovations \pm 2 S.E. Response of REPO to EXCESS_RESERVE

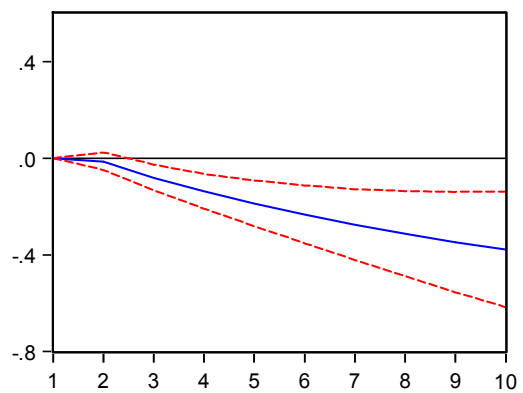

Response of EXCESS_RESERVE to EXCESS_RESERVE

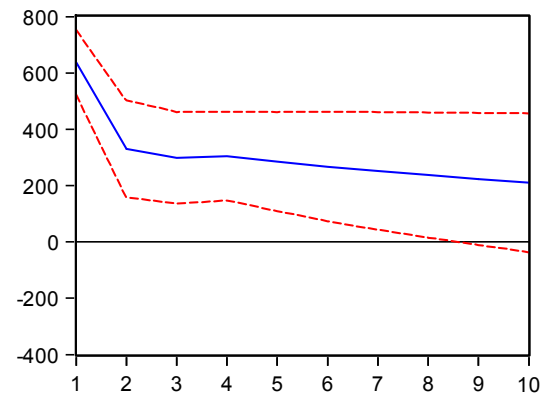

Response of DEPOSITRATE to EXCESS_RESERVE

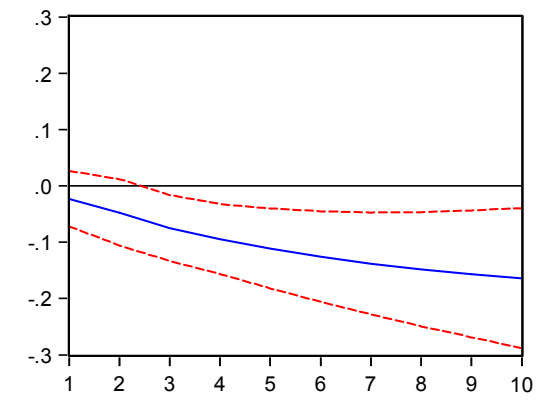

Response of REPO to DEPOSITRATE

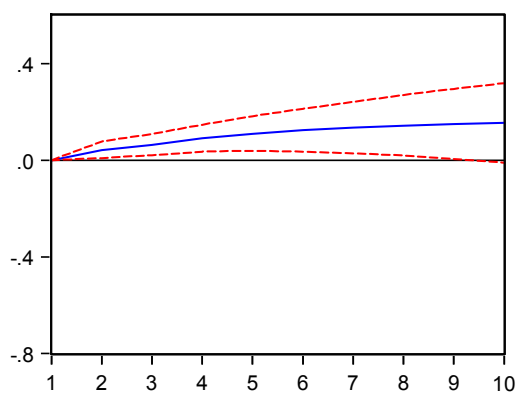

Response of EXCESS_RESERVE to DEPOSITRATE

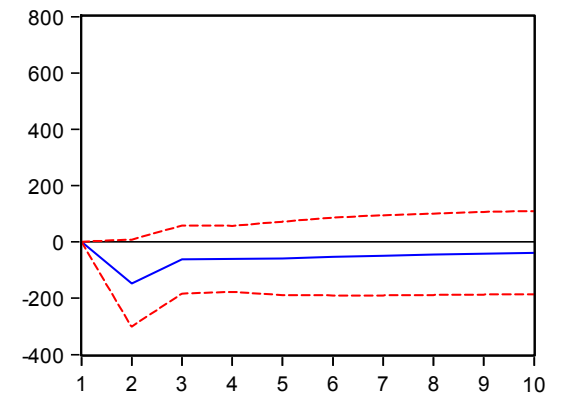

Response of DEPOSITRATE to DEPOSITRATE

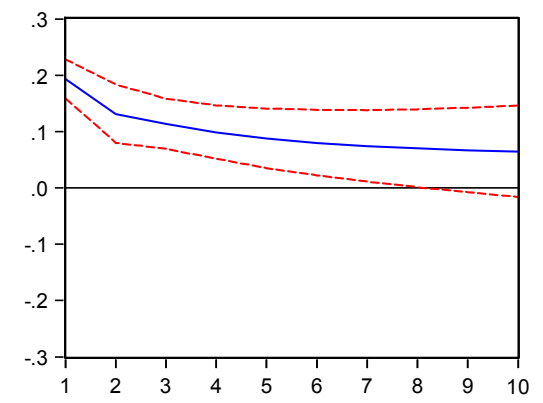


Figure 4. Excessliquidty, repo rate, and T-bill rate Response to Cholesky One S.D. Innovations \pm 2 S.E.

Response of REPO to REPO

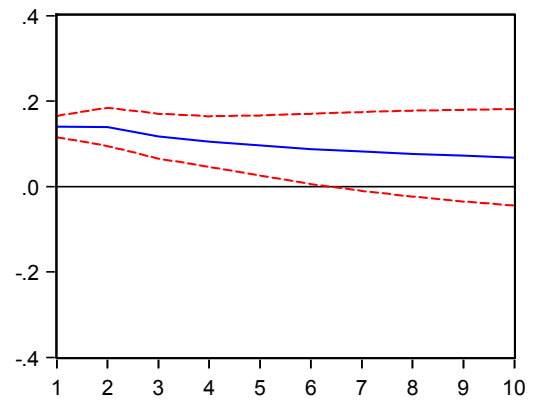

Response of EXCESS_RESERVE to REPO

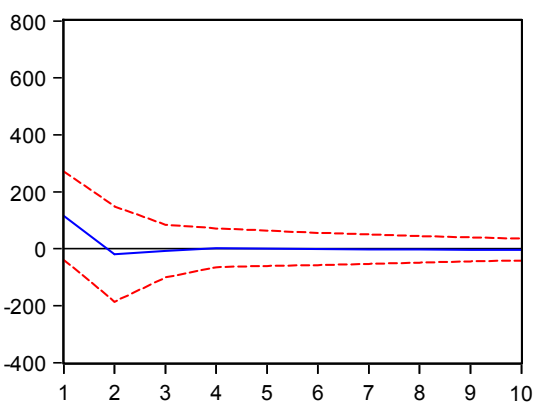

Response of TBILLRATE to REPO

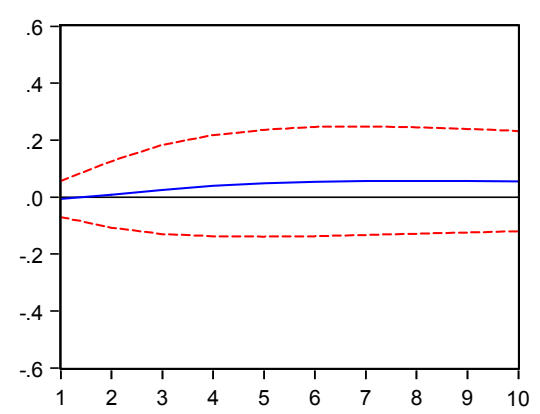

Response of REPO to EXCESS_RESERVE

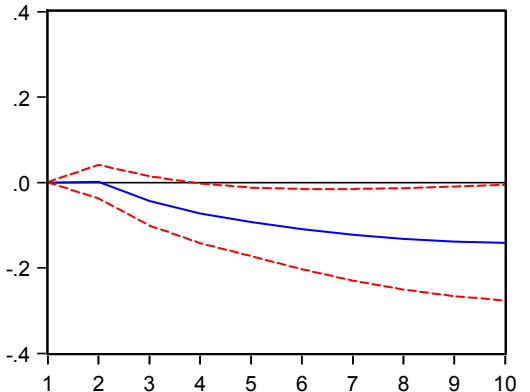

Response of EXCESS_RESERVE to EXCESS_RESERVE

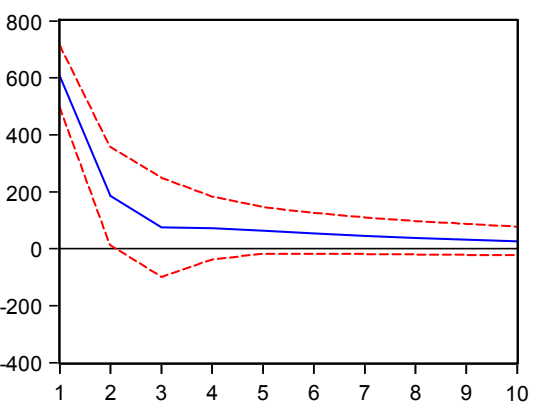

Response of TBILLRATE to EXCESS_RESERVE

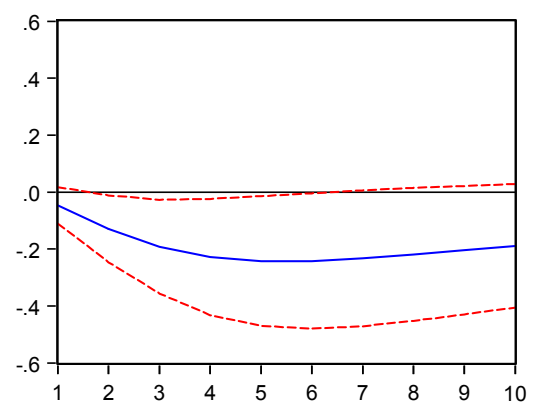

Response of REPO to TBILLRATE

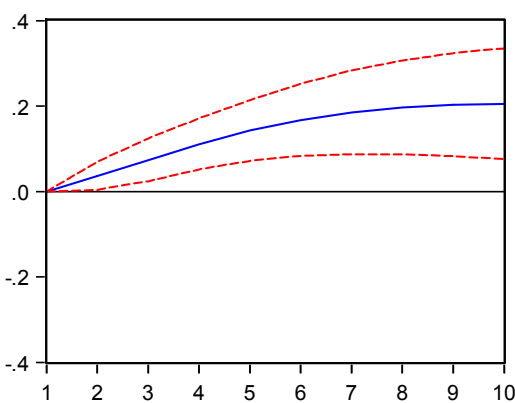

Response of EXCESS_RESERVE to TBILLRATE

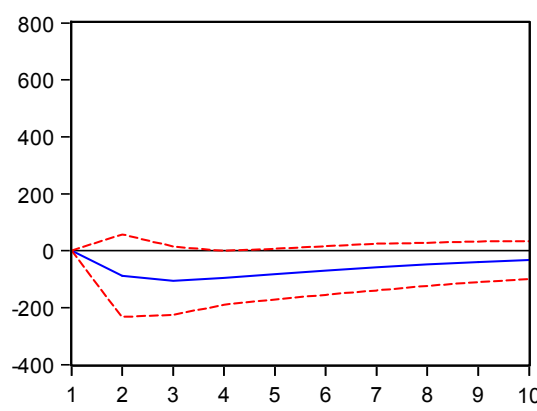

Response of TBILLRATE to TBILLRATE

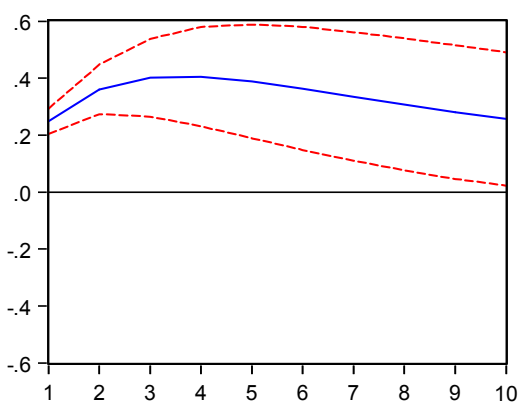


Figure 5. Repo rate and headline inflation

Response to Cholesky One S.D. Innovations \pm 2 S.E.

Response of REPO to REPO

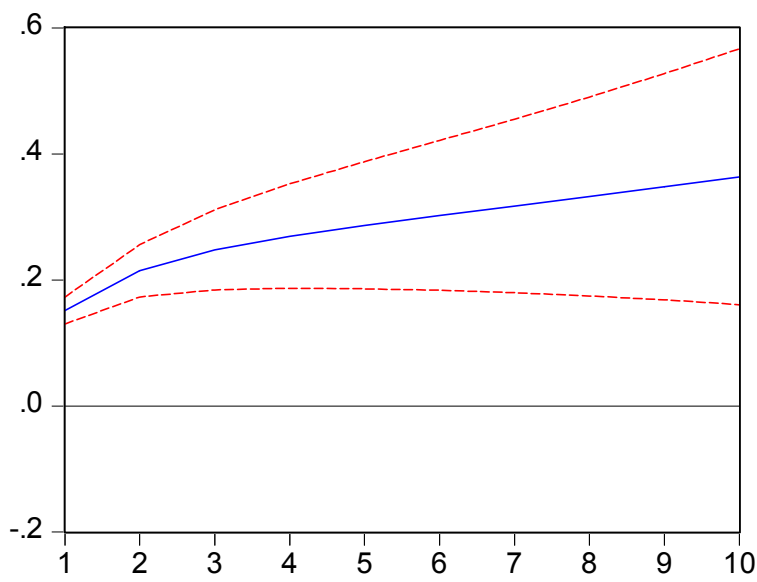

Response of INFLATION to REPO

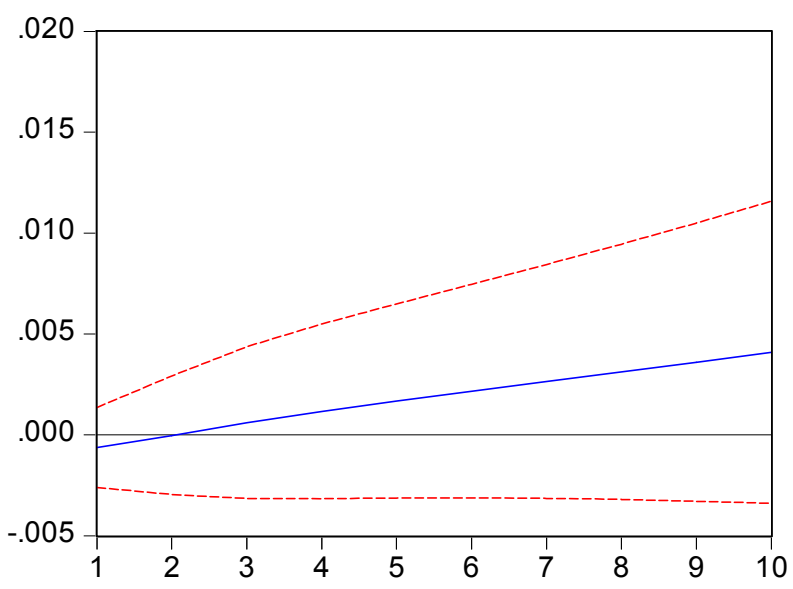

Response of REPO to INFLATION

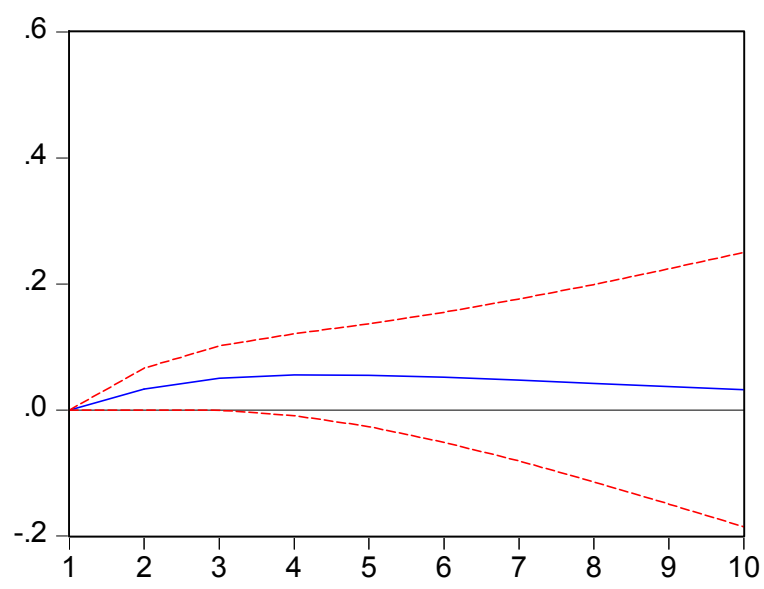

Response of INFLATION to INFLATION

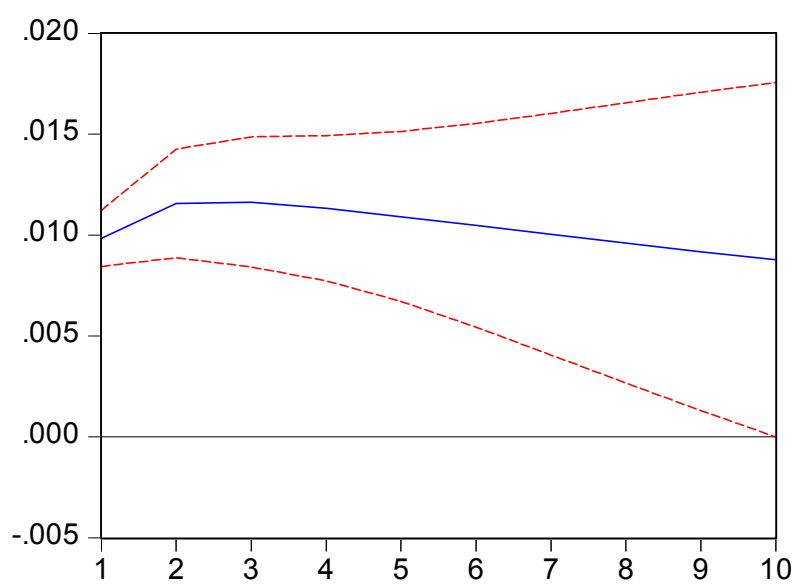


Figure 6. Repo rate and core inflation

Response to Cholesky One S.D. Innovations \pm 2 S.E.

Response of REPO to REPO

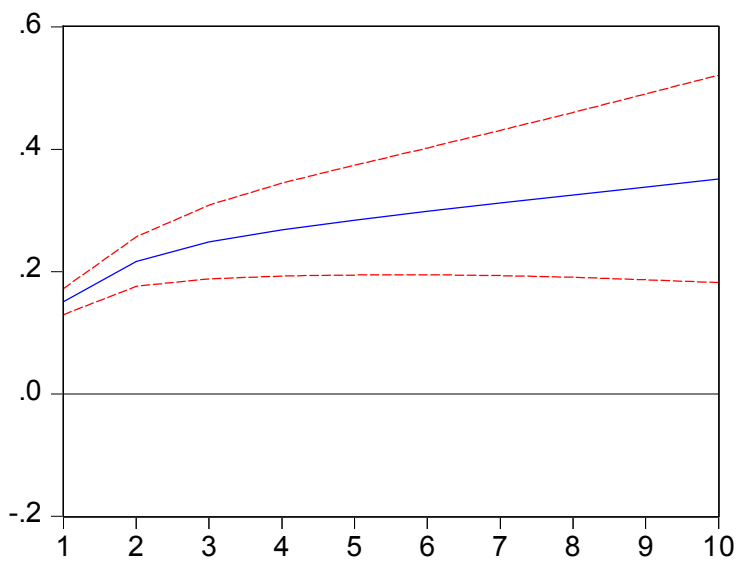

Response of INFLATIONCORE to REPO

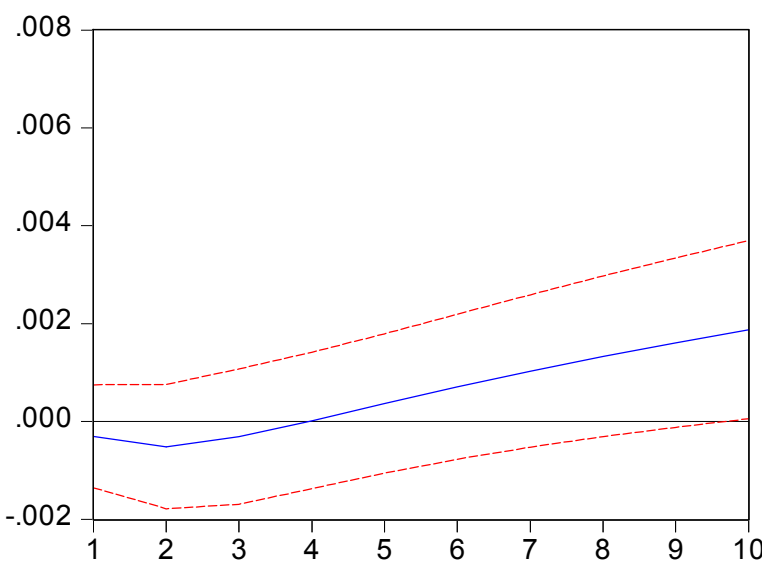

Response of REPO to INFLATIONCORE

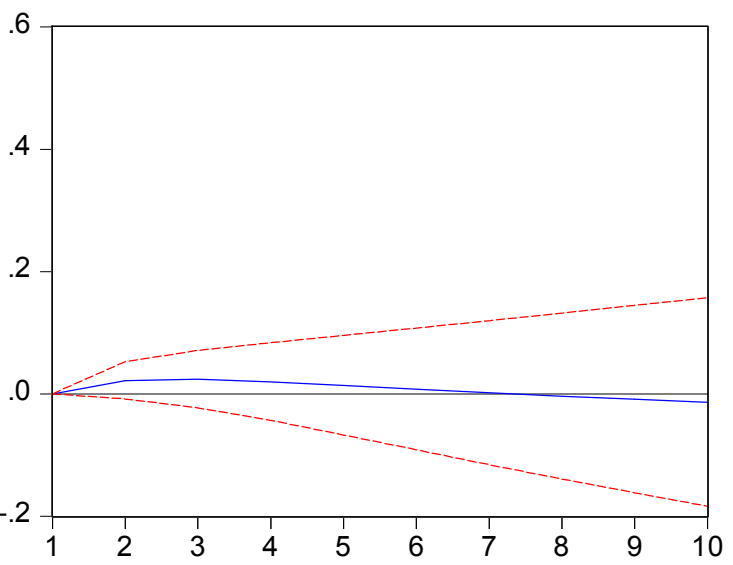

\section{Response of INFLATIONCORE to INFLATIONCORE}

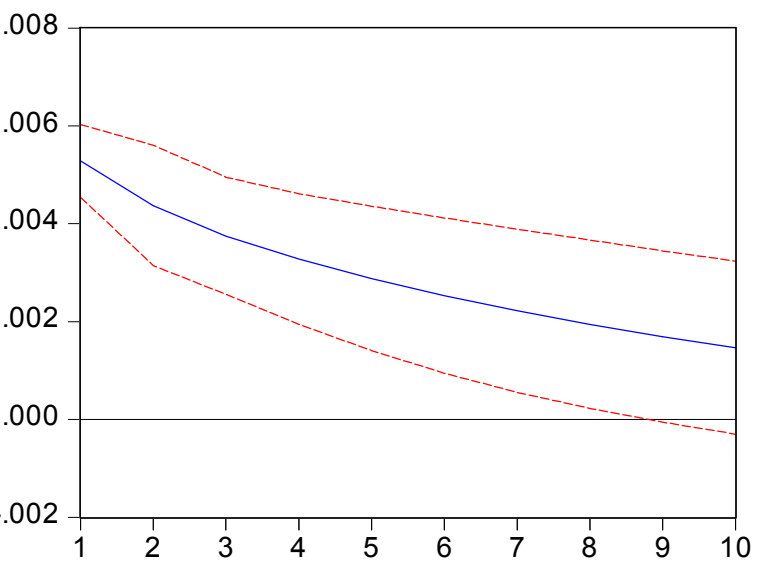


Figure 7. T-bill rate and queues

Response to Cholesky One S.D. Innovations \pm 2 S.E.

Response of TBILLD to TBILLD

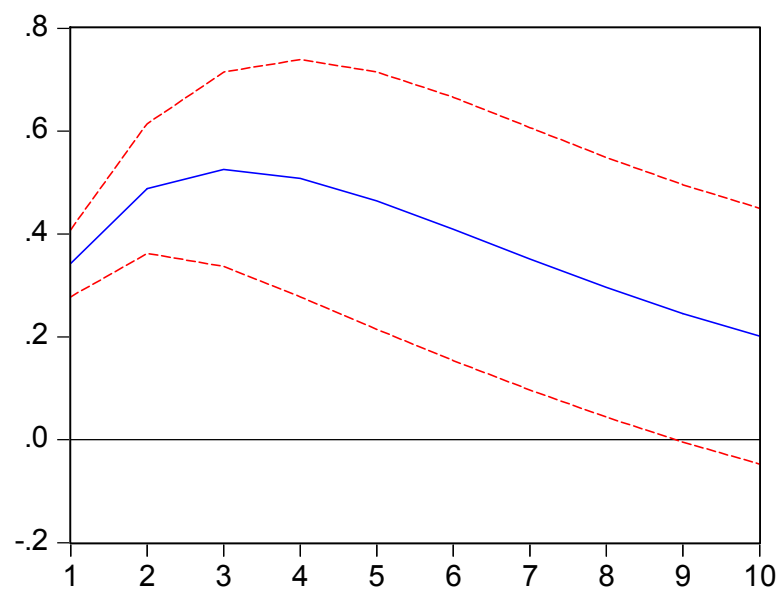

Response of QUEUES to TBILLD

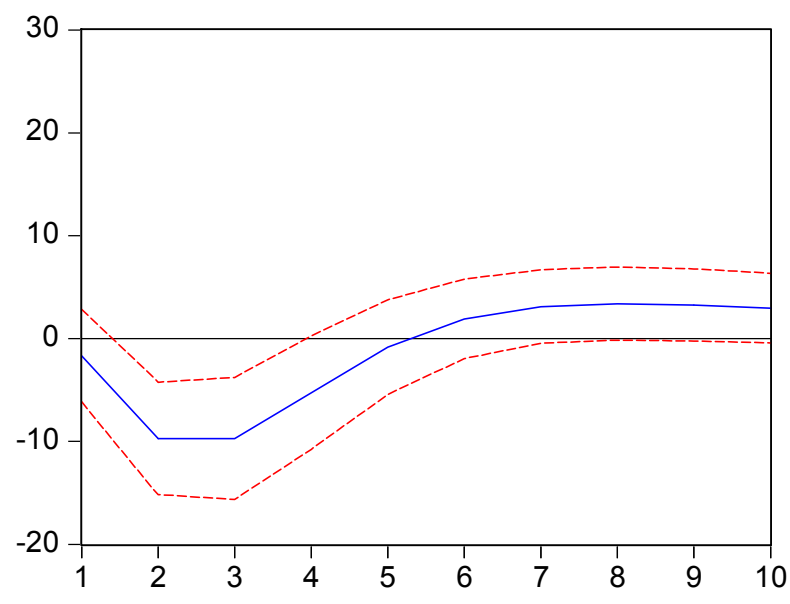

Response of TBILLD to QUEUES

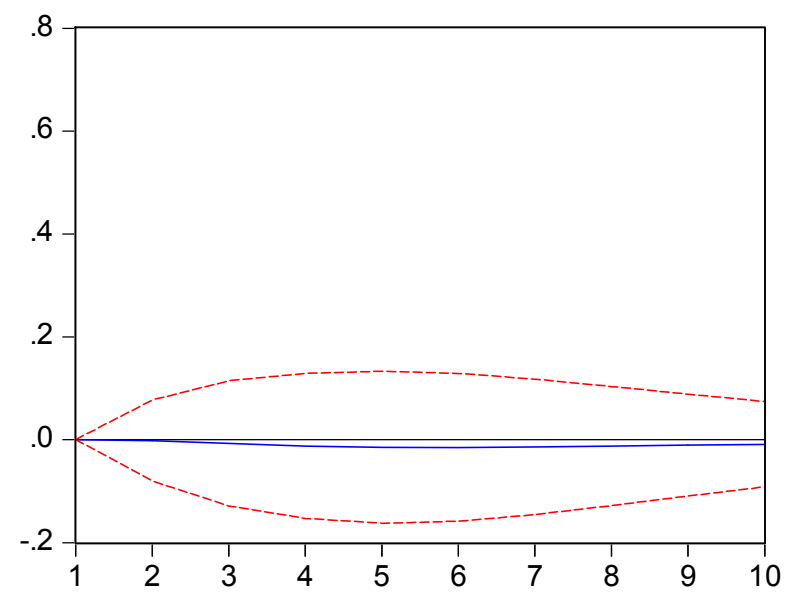

Response of QUEUES to QUEUES

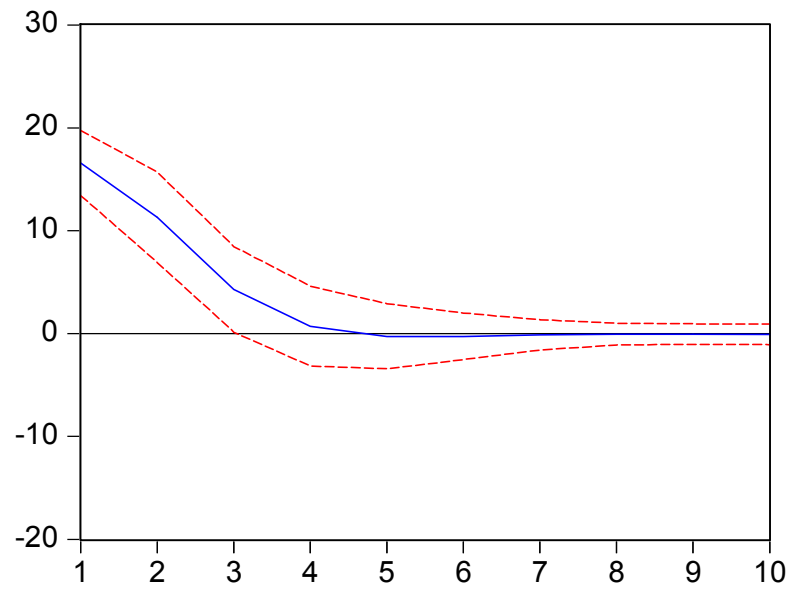


Figure 8. Deposit rate and queues

Response to Cholesky One S.D. Innovations \pm 2 S.E.

Response of DEPOSITRATED to DEPOSITRATED

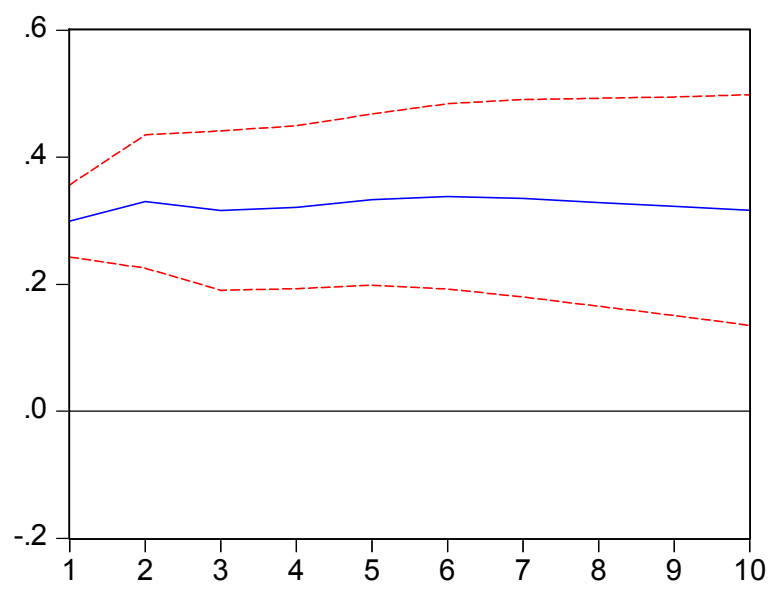

Response of QUEUES to DEPOSITRATED

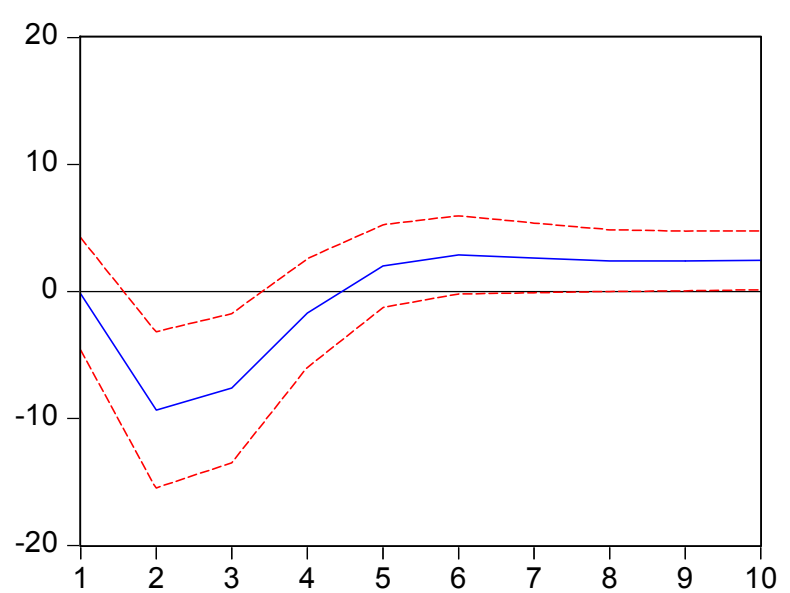

Response of DEPOSITRATED to QUEUES

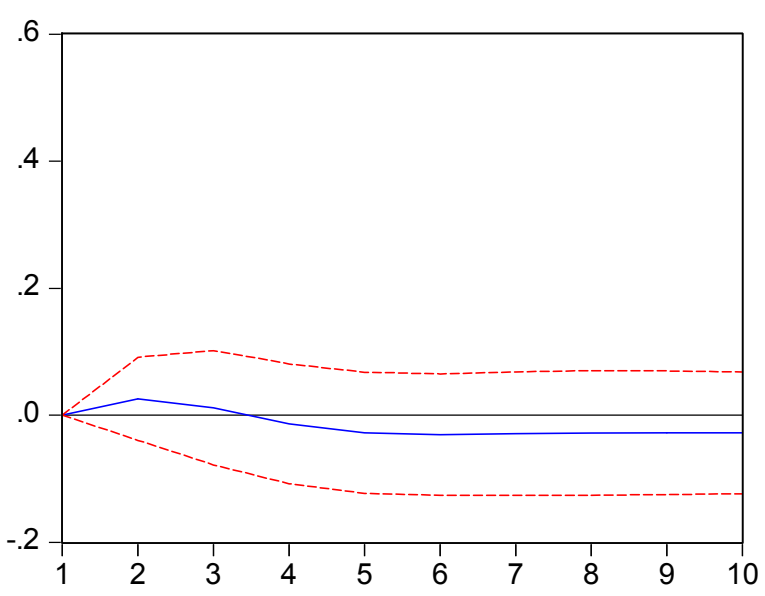

Response of QUEUES to QUEUES

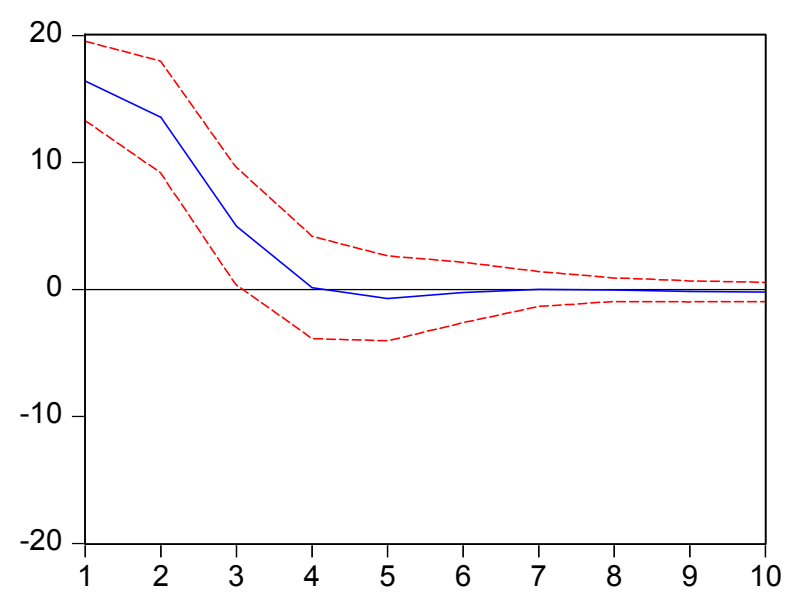


Figure 9. Repo rate and queues

Response to Cholesky One S.D. Innovations \pm 2 S.E.

Response of REPOD to REPOD

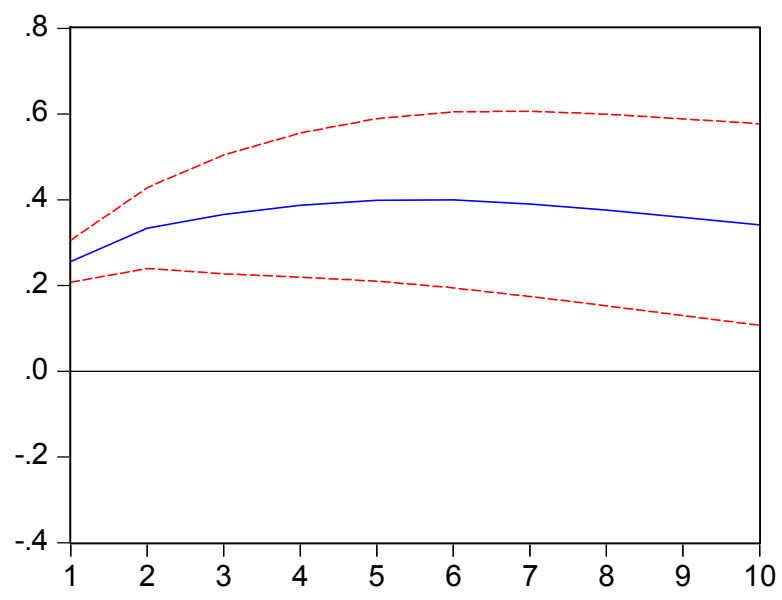

Response of QUEUES to REPOD

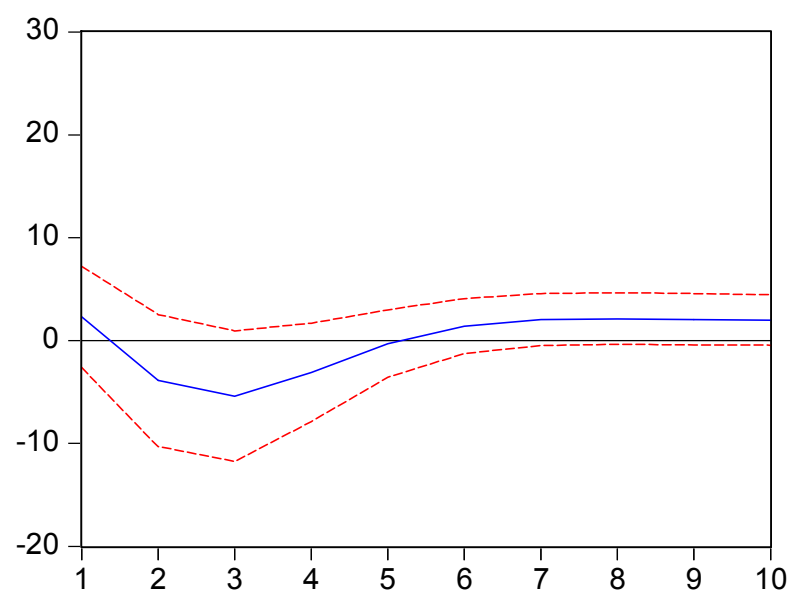

Response of REPOD to QUEUES

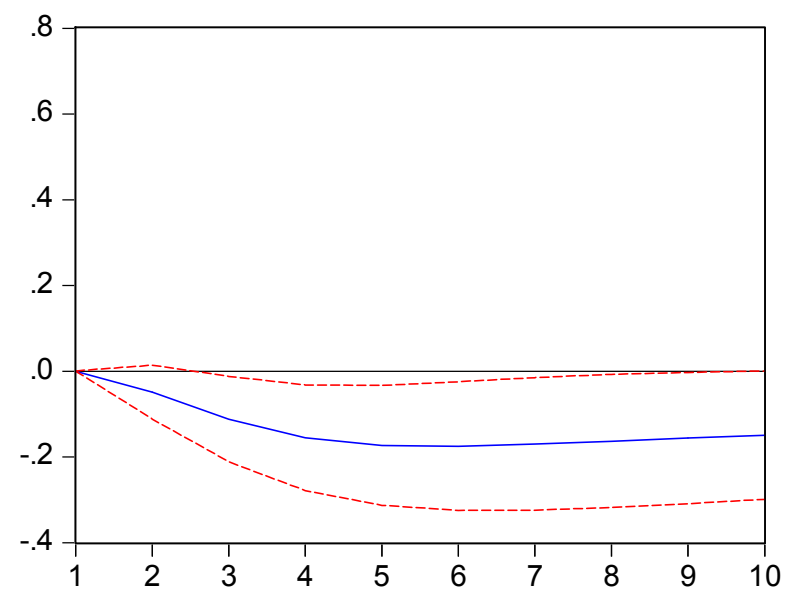

Response of QUEUES to QUEUES

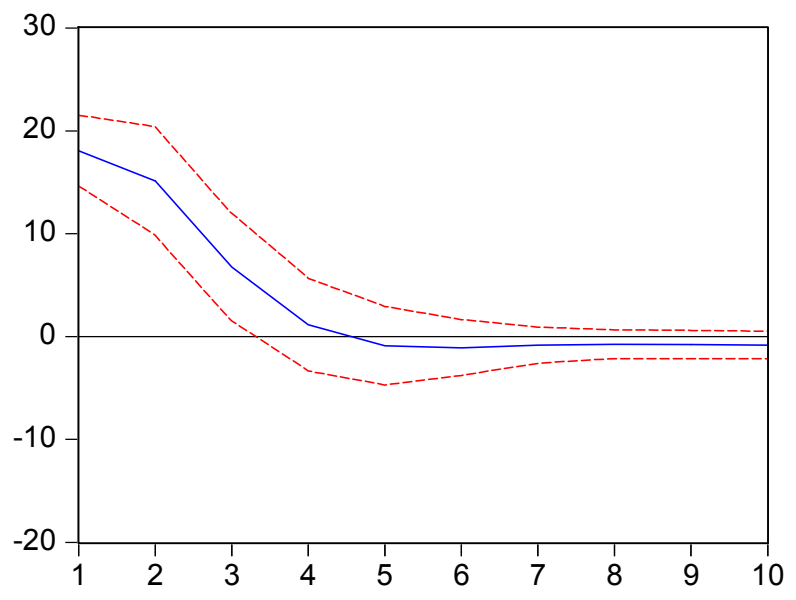




\section{References}

International Monetary Fund, 2004, "Monetary and Exchange Rate Policy," in Trinidad and Tobago-Selected Issues, IMF Country Report No. 05/6.

,2006, "The Monetary Transmission Mechanism in Trinidad and Tobago," in Trinidad and Tobago-Selected Issues, IMF Country Report 07/8. 